\title{
Bioavailability and bioefficacy of folate and folic acid in man
}

\author{
Ingeborg A. Brouwer ${ }^{1,2 *}$, Marȳke van Dusseldorp ${ }^{1} \dagger$, Clive E. West ${ }^{1,3}$ and \\ Régine P.M. Steegers-Theunissen ${ }^{2,4}$ \\ ${ }^{1}$ Division of Human Nutrition and Epidemiology, Wageningen University, The Netherlands \\ ${ }^{2}$ Department of Obstetrics and Gynaecology, University Hospital Nijmegen St Radboud, \\ The Netherlands \\ ${ }^{3}$ Department of Gastroenterology, University Hospital Nijmegen St Radboud, The Netherlands \\ ${ }^{4}$ Department of Epidemiology, University Hospital Nijmegen St Radboud, The Netherlands
}

Folic acid is important because supplementation around the time of conception has been proven to lower the risk of having offspring with a neural-tube defect. Furthermore, both dietary folate and folic acid decrease plasma total homocysteine concentrations. Elevated plasma homocysteine concentrations are considered to be an independent risk factor for cardiovascular disease. The aim of the present review is to give an overview of factors influencing bioavailability and bioefficacy (the proportion of ingested nutrient converted to its active form) of food folate and folic acid, and to discuss the functional bioefficacy of folate and folic acid in decreasing plasma homocysteine concentrations. We use the mnemonic SLAMENGHI to group factors influencing bioavailability and bioefficacy: Species of folate; Linkage at molecular level; Amount of folate and folic acid consumed; Matrix; Effect modifiers; Nutrient status; Genetic factors; Host-related factors; mathematical Interactions between the various factors. Bioefficacy of folate from some foods is $<50 \%$ that of folic acid. This factor is most probably explained by the matrix factors, encapsulation and binding. However, often such effects cannot be distinguished from factors such as species, chain length of folate in food, effect modifiers and the amount of folate consumed in a meal. Folic acid provided as a supplement is well absorbed. However, the homocysteine-lowering capacity of doses of folic acid $>500 \mu \mathrm{g}$ is limited. It is unclear whether unmetabolised folic acid poses health risks. This factor is of importance, because food fortification is now implemented in many countries and folic acid supplements are freely available. In particular circumstances host-related factors, such as gastrointestinal illness and $\mathrm{pH}$ of the jejunum, can influence

*Corresponding author: Dr Ingeborg A. Brouwer, present address Wageningen Centre for Food Sciences, PO Box 8129, 6700 EV Wageningen, The Netherlands, fax +33317 483342, email: ingeborg.brouwer@staff.NutEpi.wau.nl

$\dagger$ Present address: Department of Consumer Studies and Epidemiology, TNO Nutrition, Zeist, The Netherlands. 
bioavailability. Genetic factors also deserve attention for future research, because polymorphisms may influence folate bioavailability.

\section{Folate: Folic acid: Bioavailability: Bioefficacy: Homocysteine}

\section{Introduction}

Folate is a $\mathrm{B}$ vitamin that serves as a methyl group donor in $\mathrm{C}_{1}$ metabolism. The term folate refers to all derivatives with the biological activity of pteroylmonoglutamic acid (folic acid). Folic acid is the synthetic fully-oxidised form of pteroylglutamic acid monoglutamate; it is not present in significant quantities in nature but is synthesised commercially. In nature various reduced forms of folate with one or more glutamate moieties occur.

During the last decade folic acid has received much attention because new functions, apart from those related to the classical treatment of megaloblastic anaemia, have been discovered. Folic acid supplementation around the time of conception has been proven to make a contribution to the prevention of neural-tube defects (Medical Research Council Vitamin Study Research Group, 1991; Czeizel \& Dudás, 1992). The Federal Government of the USA responded to these findings by introducing mandatory fortification of grain products with folic acid. This fortification programme stresses the importance of understanding the factors that affect the bioavailability (the proportion of the ingested amount available for metabolic processes) of folic acid added to foods.

Furthermore, dietary folate and folic acid both decrease total homocysteine levels in plasma effectively (Homocysteine Lowering Trialists' Collaboration, 1998; Brouwer et al. 1999). This factor is important because elevated plasma homocysteine concentrations have been identified as an independent risk factor for cardiovascular disease (Boushey et al. 1995; Graham et al. 1997). Plasma homocysteine concentrations can be regarded as a functional indicator of folate status (Jacob et al. 1995).

The present review examines the factors influencing bioavailability and bioefficacy of natural food folate and folic acid from fortified food products. (Bioefficacy is the proportion of the ingested nutrient converted to an active form of the nutrient; here the proportion of folate or folic acid converted to 5-methyltetrahydrofolate. Bioefficacy is a function of bioavailability and is often referred to as bioconversion.) The functional bioefficacy of folate and folic acid in decreasing plasma homocysteine levels is also discussed.

\section{Intestinal absorption}

Dietary folates are a mixture of various mono- and pteroylpolyglutamates (with two to seven glutamate moieties). Before absorption in the jejunum, dietary polyglutamyl folates must first be deconjugated by the enzyme pteroylpolyglutamate hydrolase (folate conjugase) to a monoglutamyl form.

Before the fully-oxidised monoglutamyl form of the vitamin, folic acid, enters the portal circulation through the mucosal cells of the jejunum it is reduced to tetrahydrofolate and is either methylated or formylated (Perry \& Chanarin, 1973; Selhub et al. 1973, 1983; Strum, 1979). However, when a single dose of more than $250 \mu \mathrm{g}$ folic acid is fed, unmetabolised folic acid has been shown to be present in serum (Kelly et al. 1997). 


\section{Definition of bioavailability}

In pharmacokinetics, bioavailability is described as the area under the curve derived from an oral dose:the area under the curve derived from an intravenous reference dose (Rowland \& Tozer, 1989). However, this definition is not applicable with respect to folate bioavailability because it assumes that clearance is independent of the route of administration. This is not the case for folates (Gregory et al. 1992). As a result of the reduction and either methylation or formylation that takes place in the jejunal mucosa during absorption, it is not possible to determine absolute bioavailability, but only bioavailability relative to the bioavailability of the fullyoxidised monoglutamate (folic acid; Rogers et al. 1997).

Within our group, the definitions of bioavailability, bioconversion and bioefficacy have developed over the years and reflect our current thinking (van Lieshout et al. 2001). However, these definitions do not include activity of ingested nutrients carrying out metabolic functions. Thus, we have introduced the term 'functional bioefficacy' which is the proportion of an ingested nutrient which carries out a certain metabolic function. Since plasma total homocysteine is a functional index of folate status, changes in plasma total homocysteine concentration in response to a given intake of folate or folic acid can be used as a measure of functional bioefficacy according to this definition. Changes in plasma folate or erythrocyte folate can be regarded as measurements of bioefficacy.

\section{Factors influencing folate and folic acid bioavailability}

de Pee \& West (1996) published a review on dietary carotenoids and their role in combating vitamin A deficiency. They introduced the mnemonic 'SLAMANGHI' to order the factors influencing the bioavailability of carotenoids (de Pee \& West, 1996), and the word was subsequently modified to SLAMENGHI (Castenmiller \& West, 1998). The SLAMENGHI factors are not specific for carotenoid bioavailability, but can also be applied to the bioavailability and bioefficacy of other nutrients. In the present review we will discuss the factors influencing bioavailability and bioefficacy of folate with reference to SLAMENGHI: Species of folate; Linkage at molecular level; Amount of folate and folic acid consumed; Matrix; Effect modifiers; Nutrient status; Genetic factors; Host-related factors; mathematical Interactions between the various factors.

\section{Species of folate}

In this section the effects of different species of folate, particularly on bioefficacy, will be discussed. Folate occurs in many different forms. As discussed earlier (p. 268), folic acid (the major synthetic compound, which exists only in small amounts in nature) is the fully-oxidised monoglutamate form of the vitamin and does not have moieties that can be transferred as $\mathrm{C}_{1}$ units. The more reduced forms of folate, dihydrofolate and tetrahydrofolate can be substituted with such moieties (Wagner, 1995). These reduced forms, e.g. 5-methyltetrahydrofolate and formyltetrahydrofolates, are much more common in nature.

The bioefficacy of oxidised and reduced folates with or without various $\mathrm{C}_{1}$ units has been investigated in a series of intervention studies with human subjects (Table 1). Findings from these studies are not consistent. Perry \& Chanarin (1970) found a greater increase in serum folate levels after ingestion of reduced folates than after ingestion of folic acid. However, urinary excretion of folic acid was higher than that of the other monoglutamyl forms of folate 


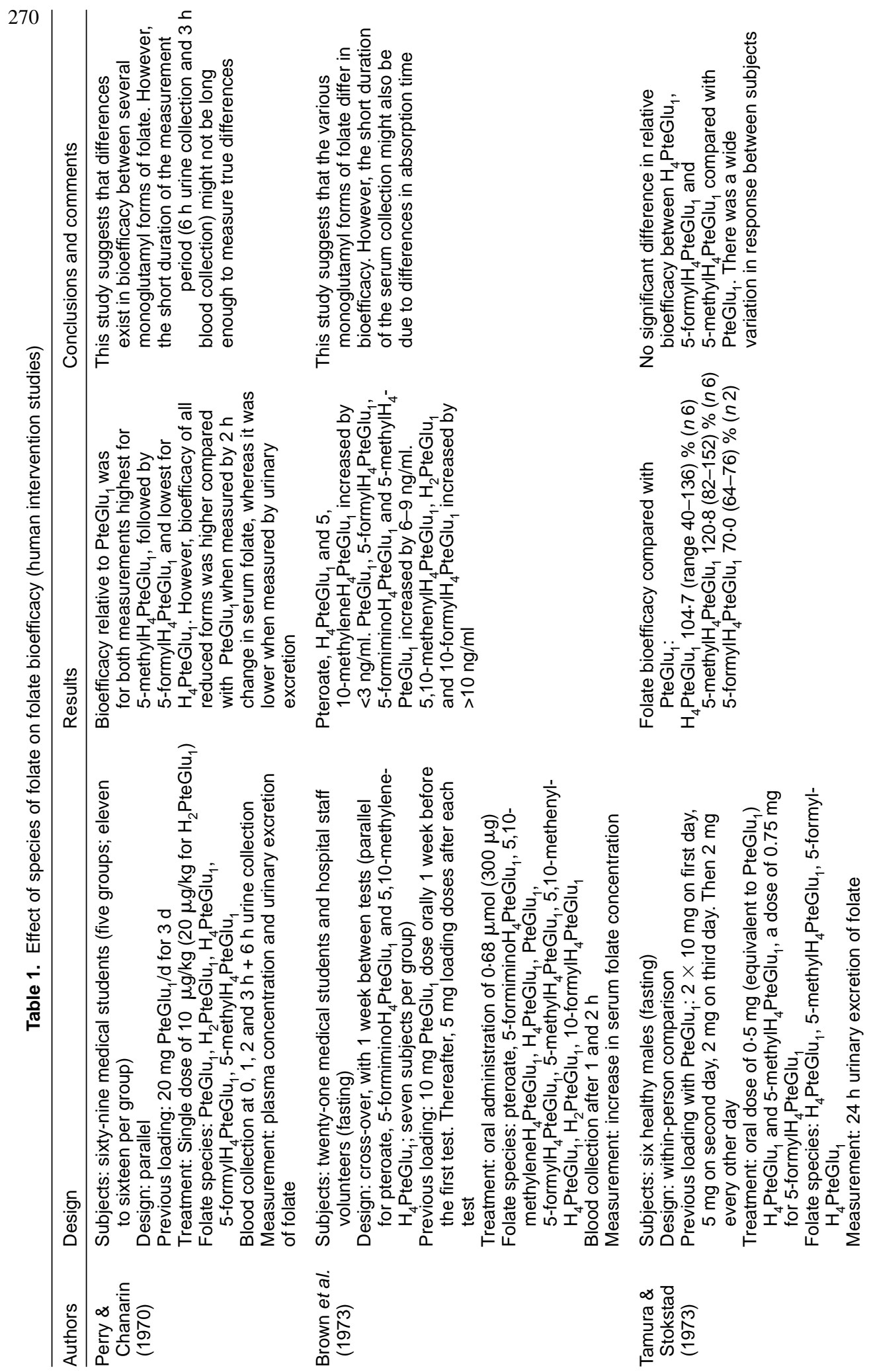




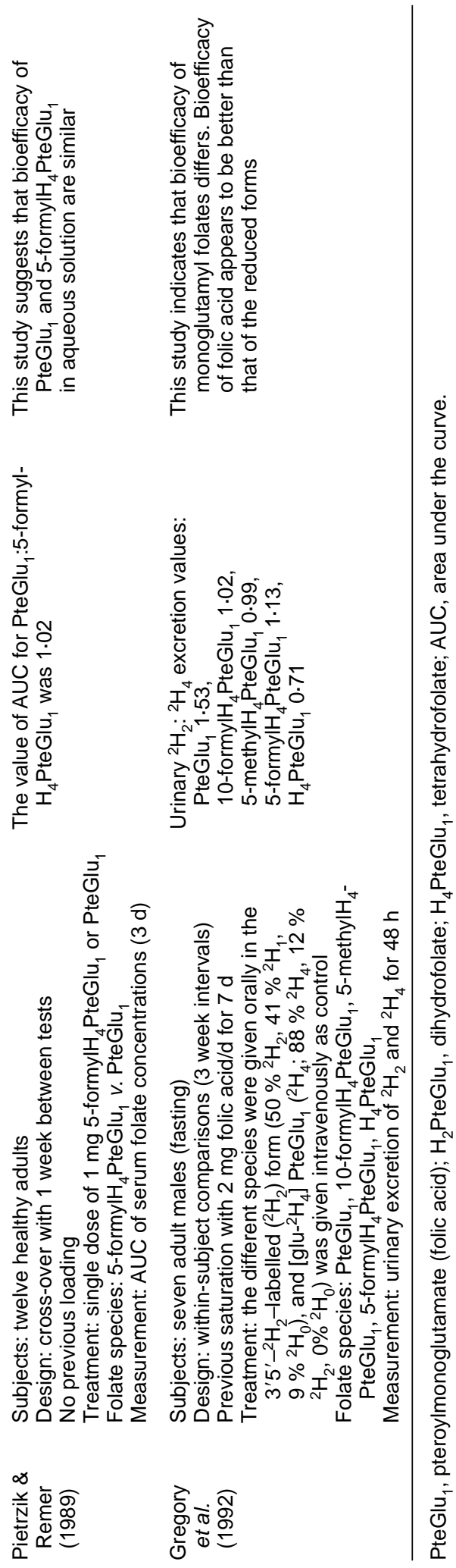


(Perry \& Chanarin, 1970). Brown et al. (1973) found that the bioefficacy of other monoglutamate forms was greater than that of folic acid, except that the bioefficacy of 5-formyltetrahydrofolate was similar and that of tetrahydrofolate was less (Brown et al. 1973). On the basis of a study using urinary excretion of orally-administered folates labelled with ${ }^{2} \mathrm{H}_{2}$ :intravenously-administered folic acid labelled with ${ }^{2} \mathrm{H}_{4}$, Gregory et al. (1992) concluded that folic acid was more bioavailable than the reduced forms of the vitamin. Other studies have found no differences in bioefficacy between folic acid and the reduced forms (Tamura \& Stokstad, 1973; Pietrzik \& Remer, 1989; Bhandari \& Gregory, 1992).

One problem with most studies investigating folate bioefficacy is that the variation in response between subjects can be quite substantial. Another problem is that it is not possible to determine whether these differences are caused by differences in absorption (bioavailability) or in post-absorption processes (bioconversion). In all studies, except that of Pietrzik \& Remer (1989), subjects received one or more doses of folic acid for periods up to $7 \mathrm{~d}$ in order to saturate the tissues with folic acid.

To our knowledge there are no studies published investigating the effect of different species of folate on plasma total homocysteine concentrations, i.e. on functional bioefficacy.

\section{Linkage at molecular level}

Folate not only occurs as different species as discussed earlier, but also with more than one glutamate moiety. In this section the bioefficacy in human volunteers of folate with different numbers (one to seven) of glutamate moieties in the side chain will be discussed (Table 2).

As stated earlier, pteroylpolyglutamates are the major forms of folate in foods, and first have to be hydrolysed to monoglutamates before absorption in the small intestine can take place. A conjugase present in the jejunum is responsible for removing glutamate moieties from pteroylpolyglutamates (Reisenauer et al. 1977). Under normal circumstances, the activity of this folate conjugase enzyme is not rate limiting in the absorption process (Reisenauer \& Halsted, 1987). This finding is in line with those from earlier studies using ${ }^{3} \mathrm{H}$-labelled folate. The heptaglutamate is absorbed nearly as well as the monoglutamate (Rosenberg \& Godwin, 1971; Godwin \& Rosenberg, 1975). Two studies using 24 h urinary excretion of folate and the area under the curve of serum folate concentrations also found no significant differences in bioavailability of mono-, tri- and heptaglutamates (Tamura \& Stokstad, 1973; Bailey et al. 1988). However, a well-designed study using labelled folates suggested that the bioavailability of hexaglutamate is less than that of the monoglutamate (Gregory et al. 1991). Earlier studies also suggested that less of the monoglutamate disappeared from the jejunum than the heptaglutamate (Halsted et al. 1975, 1978). Although the results of the studies are not unequivocal, absorption of the polyglutamates is often found to be less than that of the monoglutamate. This may imply that bioavailability of polyglutamates is less than that of monoglutamates. However, it cannot be excluded that uptake of polyglutamates takes longer, and that the net effect in the long term is similar to that of monoglutamates.

\section{Amount of folate and folic acid}

Bioavailability of folate or folic acid is likely to be influenced by the amount ingested. For absorption, there are two different transport systems. In the first transport system folates are bound to membrane-associated folate-binding proteins and transported across the brush-border 


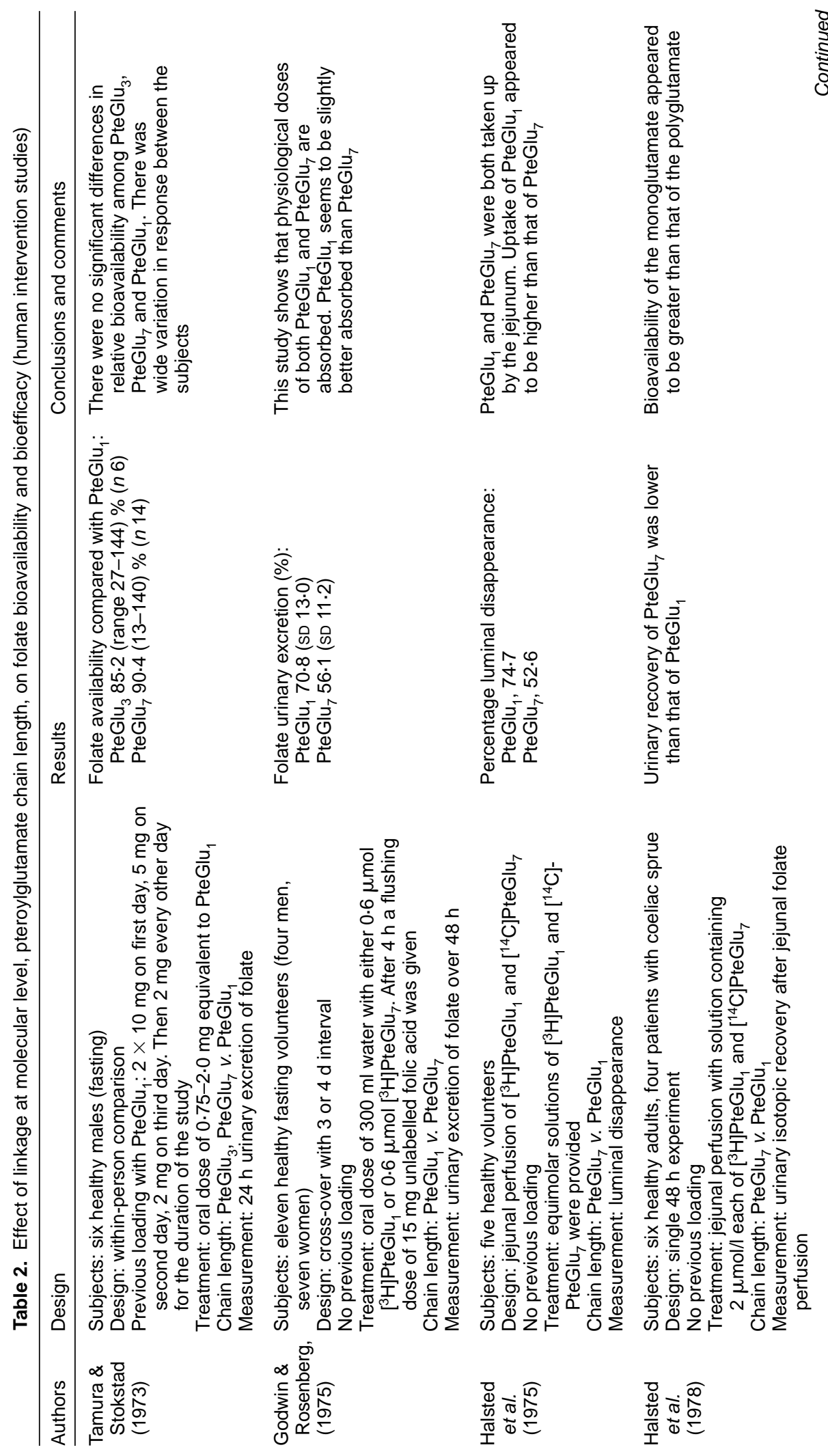




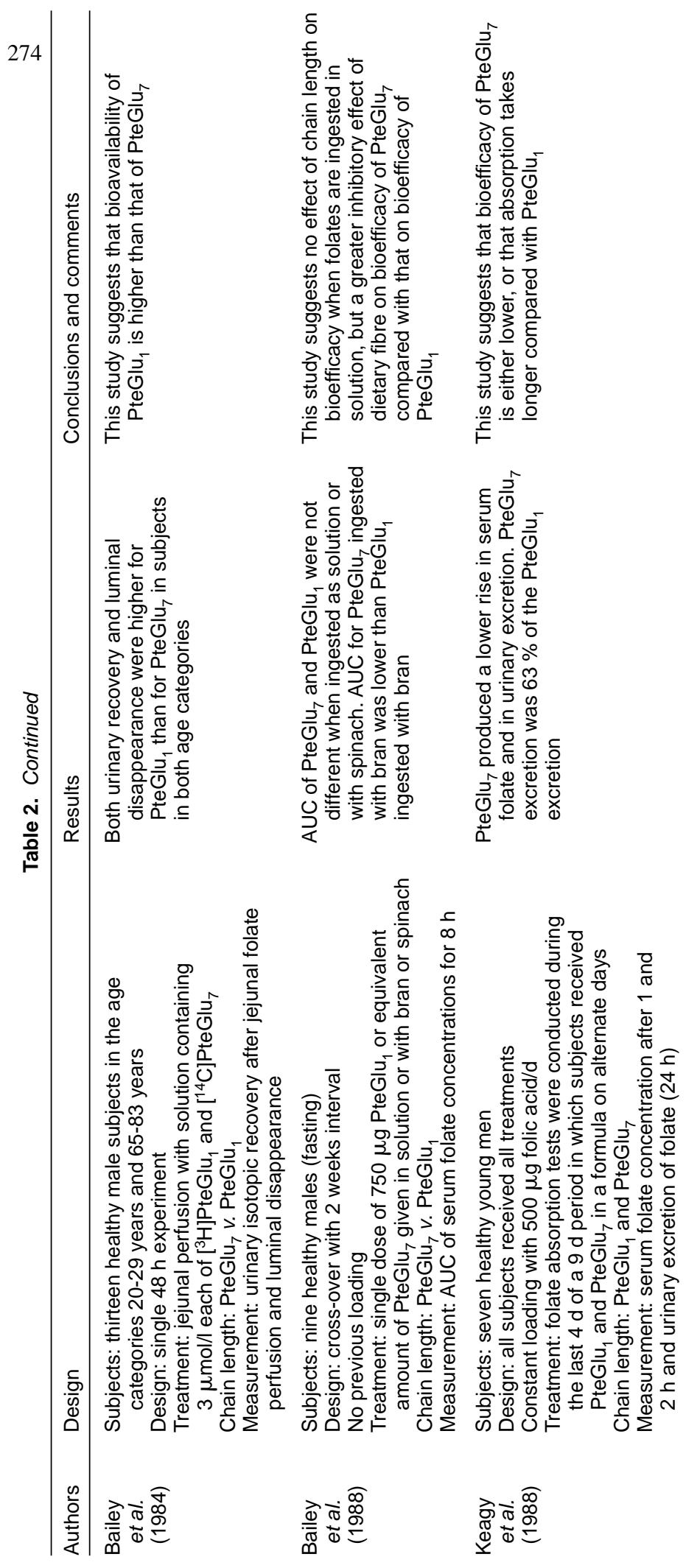




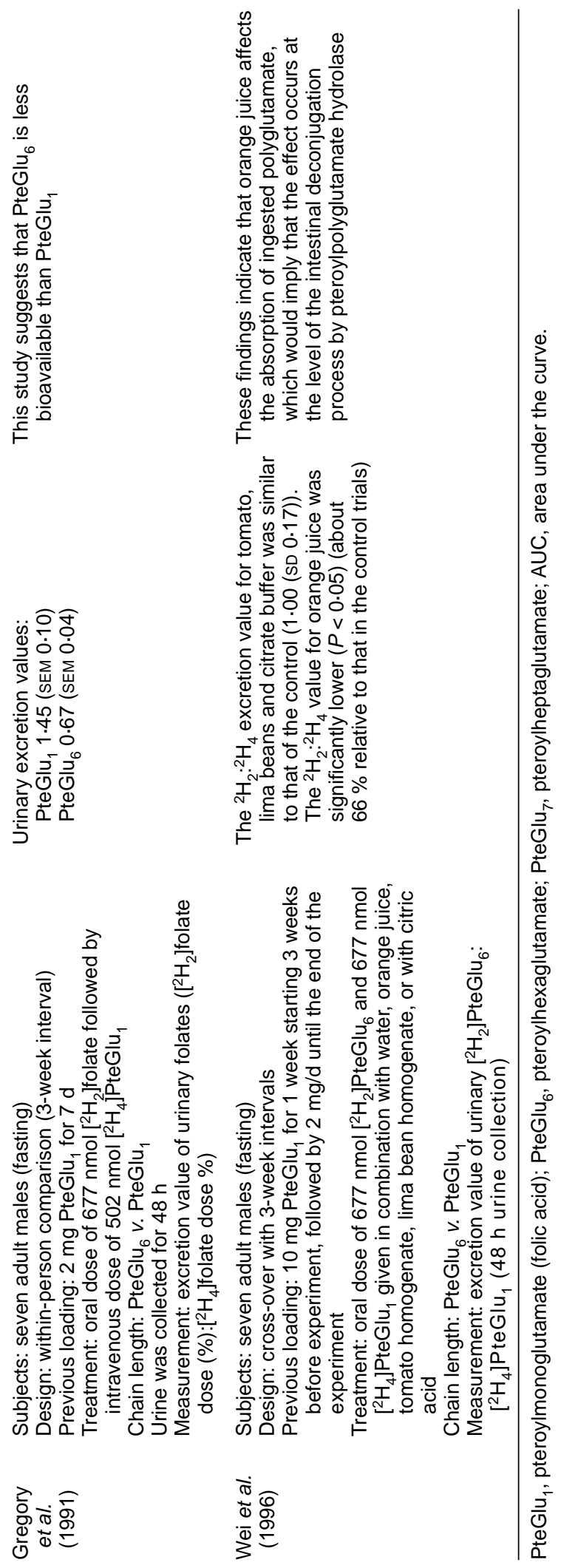


membrane by a carrier-mediated mechanism. However, at high intraluminal concentration of folate $(>10 \mu \mathrm{mol} / \mathrm{l})$ a second non-saturable diffusion-mediated transport system plays a major role in folate absorption (Mason, 1990). The effect of the amount ingested is most likely to be of significance if the saturable transport system is saturated. At physiological concentrations ( $<5 \mu \mathrm{mol} / \mathrm{l})$ of folate in the lumen, transport occurs mainly via the saturable transport system (Mason, 1990). A level of intake that causes saturation of this transport system is unlikely to be reached with normal intakes of natural folate from food, but could easily be reached with synthetic folic acid.

Many studies have investigated effects of the amount of synthetic folic acid (pteroylmonoglutamate) on bioefficacy (Table 3). Heseker \& Schmitt (1987) showed that plasma folate concentrations reached a steady-state after 4 weeks of supplementation with $1 \mathrm{mg}$ folic acid/d. Levels in erythrocytes increased over the total intervention period of 17 weeks. This pattern synchronises with the lifetime of the erythrocyte, which is known to incorporate folate only during erythropoiesis (Shane, 1995). Truswell \& Kounnavong (1997) provided subjects with folic acid supplements, containing 100, 500 or $1000 \mu \mathrm{g}$ folic acid/d, for 3 weeks in addition to the regular diet. The greatest relative increase in plasma folate was provided by the $100 \mu \mathrm{g}$ folic acid dose, while the greatest absolute increase was established by the $1000 \mu \mathrm{g}$ dose. The study does not make clear whether the same level of serum folate can be reached in the long term (Truswell \& Kounnavong, 1997). Malinow et al. (1998) also showed in a cross-over study that a dose of $127 \mu \mathrm{g}$ folic acid/d for 5 weeks was relatively more effective in raising plasma folate $(30.8 \%)$ than doses of $499(64.8 \%)$ and $665(105.7 \%) \mu \mathrm{g} / \mathrm{d}$. This observation suggests that low doses of folic acid increase plasma folate concentrations more effectively than do higher doses. However, the effect on raising plasma folate concentrations may be slightly underestimated in the groups receiving the higher doses, because the wash-out period between the intervention periods was only 5 weeks (Malinow et al. 1998). This period is probably too short to avoid carry-over effects (Brouwer et al. 1999).

As discussed earlier, the effect of folic acid on plasma total homocysteine concentrations can be described as functional bioefficacy. Many authors have investigated the effect of different amounts of folic acid on plasma total homocysteine concentrations. In a meta-analysis (Homocysteine Lowering Trialists' Collaboration, 1998) Clarke compared most of these studies. This meta-analysis showed similar homocysteine-lowering effects for doses between 0.5 and $5 \mathrm{mg}$ folic acid. Thus, it it would appear that doses of folic acid $>500 \mu \mathrm{g}$ folic acid/d have no additional homocysteine-lowering effect. In addition to the studies included in the metaanalysis, a few other studies have examined the effect of lower doses of folic acid on plasma total homocysteine concentrations. Ward et al. (1997) showed that $200 \mu \mathrm{g}$ folic acid/d had a similar effect to that of $400 \mu \mathrm{g}$ folic acid/d. However, 6 weeks of supplementation with $100 \mu \mathrm{g}$ folic acid/d was not sufficient to reach a similar level of plasma total homocysteine (Ward et al. 1997). The latter study does not exclude the possibility that supplementation with $100 \mu \mathrm{g}$ folic acid for a longer period would have resulted in lower concentrations of plasma total homocysteine. Malinow et al. (1998) found no significant decrease in plasma total homocysteine concentrations after 5 weeks of supplementation with $127 \mu \mathrm{g}$ folic acid/d. However, the short wash-out period between the experimental and placebo periods makes it difficult to interpret their results.

Kelly et al. (1997) found unmetabolised fully-oxidised folic acid (pteroylmonoglutamate) in serum of subjects receiving $>266 \mu \mathrm{g}$ folic acid/d. They suggest that the excess of folic acid cannot be used for lowering plasma total homocysteine. This observation is in line with other studies that show no additional homocysteine-lowering effect of doses of $>500 \mu \mathrm{g}$ folic acid/d, or even $>200 \mu \mathrm{g}$ folic acid/d (Ward et al. 1997; Bonnette et al. 1998; Homocysteine Lowering 


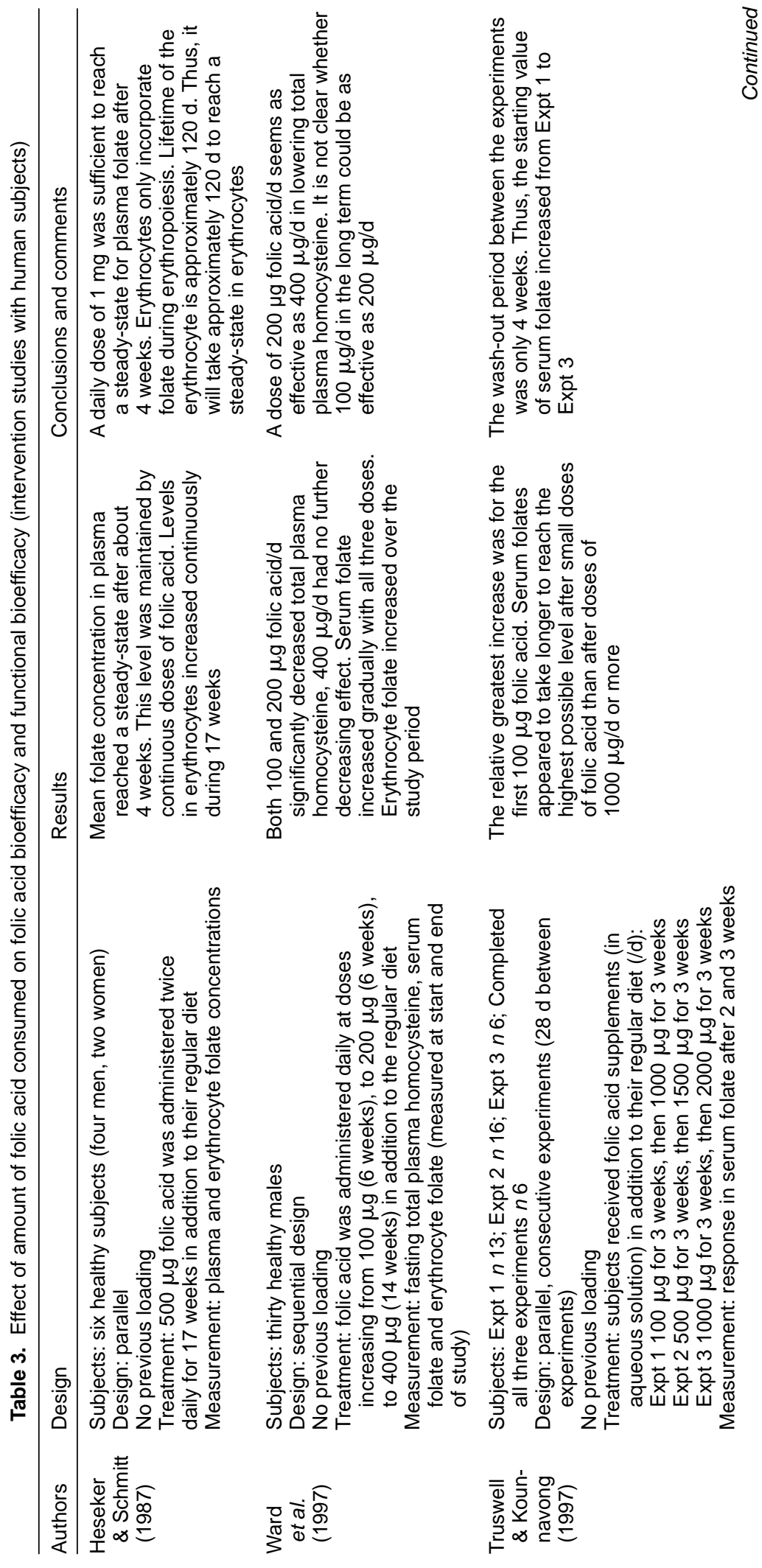



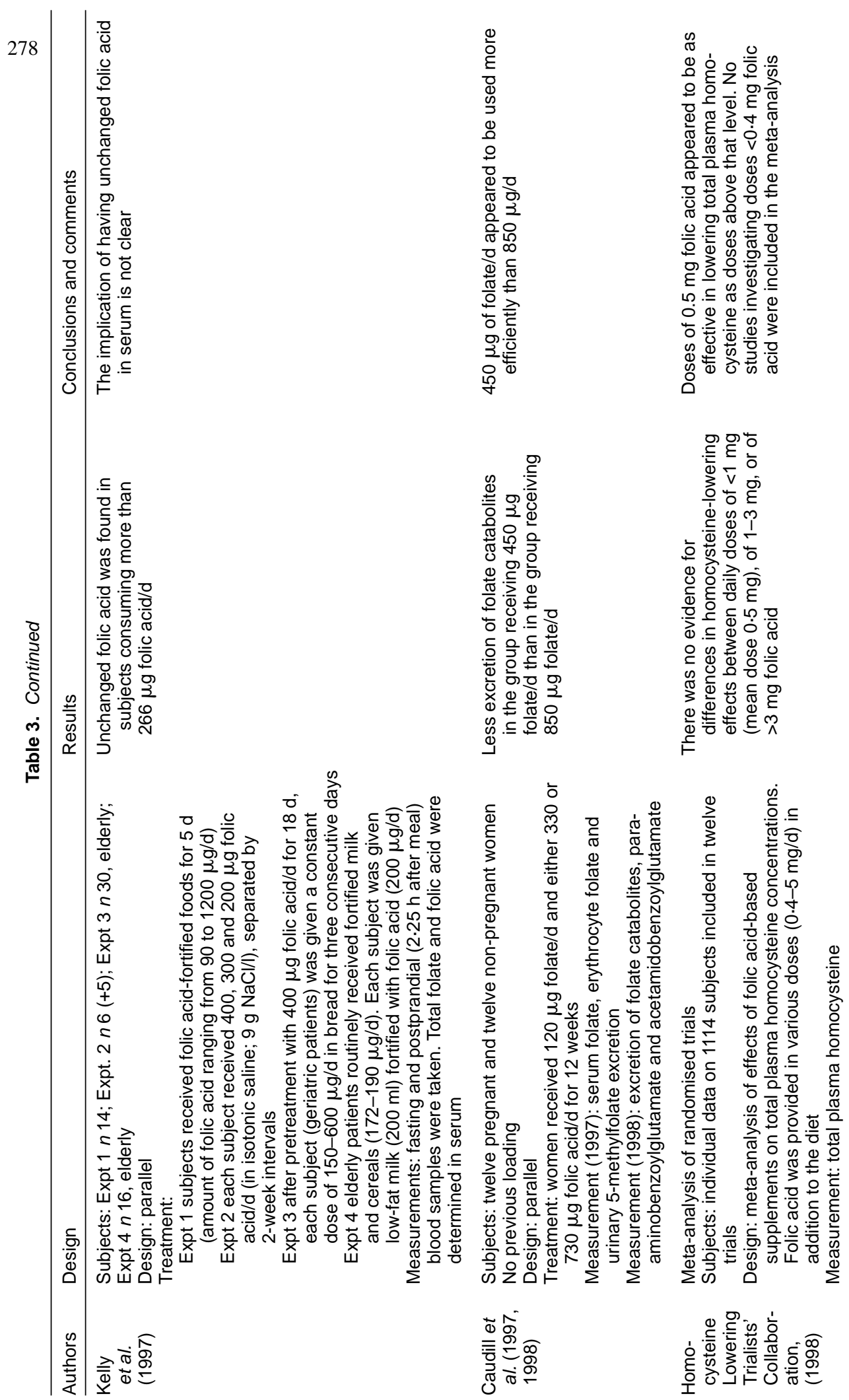


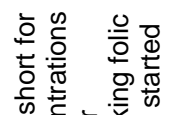

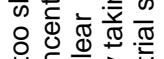

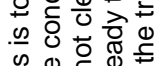

这.

这

เ人ิ

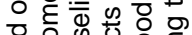

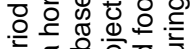

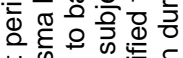

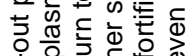

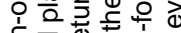

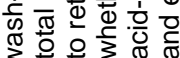

$<$

串

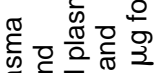

范

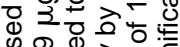

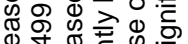

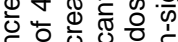

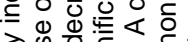

入๘

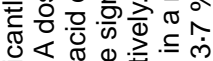

运

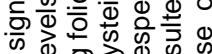

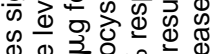

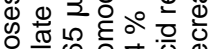

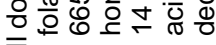

$\stackrel{\oplus}{\rightleftarrows}$

욷

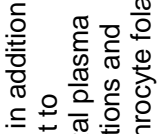

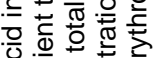

\% 응

응 क्ष

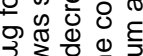

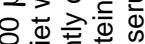

N

후은

忬

\&

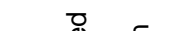

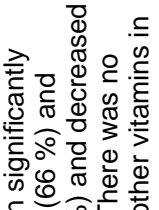

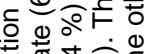

뜬

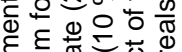

क

응 क

के 낭

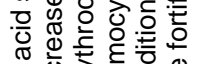

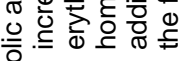

운

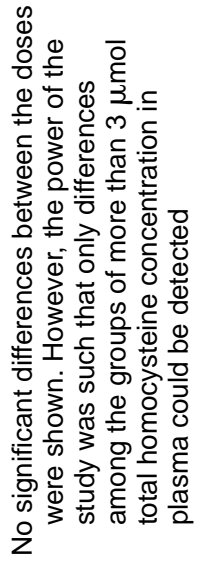

芯㐫

幽

उ

我立

들

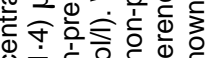

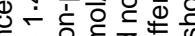

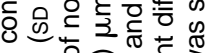

0

造边的语品

के

0

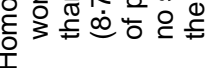

오
政

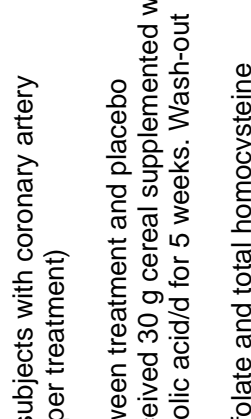

क人

资

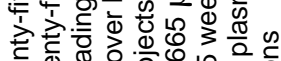

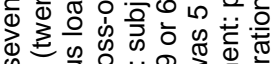

o

i.

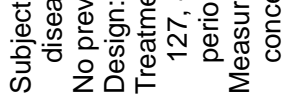

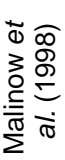
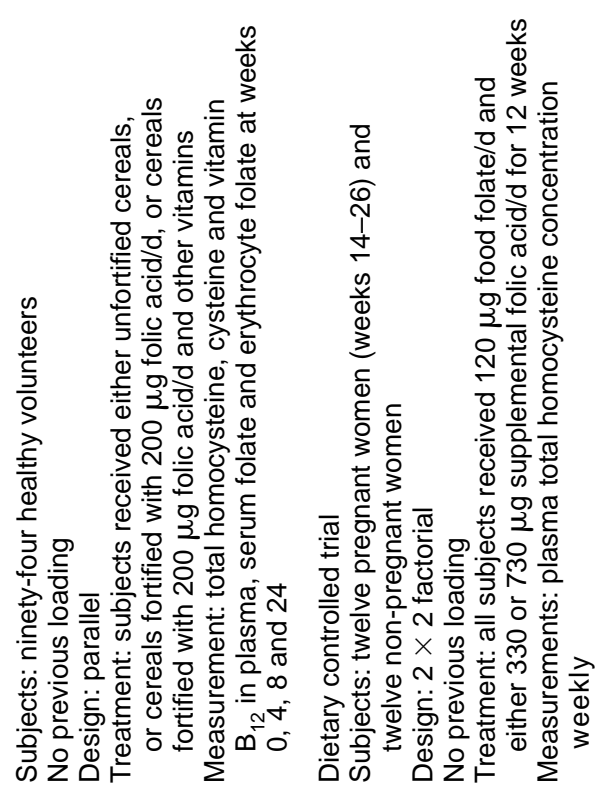

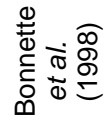


Trialists' Collaboration, 1998; Schorah et al. 1998). Thus, although bioefficacy of the excess folate can be high, its functional bioefficacy is low.

\section{Matrix}

Matrix effects on bioavailability involve both encapsulation and binding. Natural food folate can be encapsulated in plant cells or subcellular components. Generally for folic acid added to food, binding is more important, although in food preparation encapsulation may occur. Comparison of folate bioefficacy among different foods (Table 4) involves not only matrix effects, but also effects of molecular linkage, species and effect modifiers. However, studies comparing folate bioefficacy among foods cannot distinguish these factors.

Retief (1969) was one of the first researchers to study the effects of different foods on folate bioefficacy. His study is not included in Table 4 because it involved only one subject. Studies investigating the effect of food matrix of single foods on the bioefficacy of dietary folate have shown that folate is absorbed to some extent (Retief, 1969; Tamura \& Stokstad, 1973; Babu \& Srikantia, 1976; Sauberlich et al. 1987; Keagy et al. 1988). However, the bioefficacy of food folate relative to folic acid differed enormously between products (Retief, 1969; Tamura \& Stokstad, 1973; Babu \& Srikantia, 1976; Sauberlich et al. 1987; Keagy et al. 1988).

Few studies have investigated the bioefficacy of folate from mixed diets. Sauberlich et al. (1987) estimated from a strictly-controlled trial that the bioefficacy of folate in a mixed diet would be no higher than $50 \%$. Our group found that the bioefficacy of folate from vegetables and citrus fruit was $60-98 \%$ relative to that of folic acid, depending on the end point chosen. The fact that the folic acid tablets were taken every other day may have overestimated the effect of food folate slightly (Brouwer et al. 1999). Cuskelly et al. (1996) provided women on average $400 \mu \mathrm{g}$ folate/d in foods in addition to their normal diets. Since dietary intake was not strictly supervised as in controlled dietary intervention studies, and because of the small number of subjects, the power may not have been sufficient to observe a significant effect (Cuskelly et al. 1996). Riddell et al. (2000) performed a study in a non-controlled setting. They showed that intake of additional folic acid supplements and fortified cereals significantly decreased total plasma homocysteine concentrations $(P<0.001)$ and improved serum folate concentrations. Although advising subjects to increase intake of dietary folate improved their folate status and decreased total plasma homocysteine concentrations, it only significantly increased serum folate concentrations $(P<0.001)$. The study suggested that bioefficacy was less than $50 \%$ for dietary folate compared with folic acid. As the intake of dietary folate was not controlled and the subjects were provided with a list of products high in dietary folate, they may have overestimated their intake. This approach may have led to the lack of effect. The folate-rich products on the list came from several food groups. It is likely that the bioefficacy of the folate from the products ranged from good to poor (Riddell et al. 2000). A controlled dietary study carried out by Appel et al. (2000) compared diets with a modified fat content and increased intake of fruits and vegetables. The study showed that the most pronounced effects on plasma total homocysteine concentrations were seen in the group with the highest dietary folate intake. Unfortunately, it was not possible to calculate bioefficacy of folate from this study (Appel et al. 2000). Thus, folate from a mixed diet might be absorbed by more than $50 \%$. Bioefficacy would seem to be strongly dependent on the products consumed. It is difficult to predict the proportion of folate from a mixed diet that is absorbed because folate occurs in many different food products. Bioefficacy of folate from a mixed diet may also be expected to depend on factors other than the matrix. 


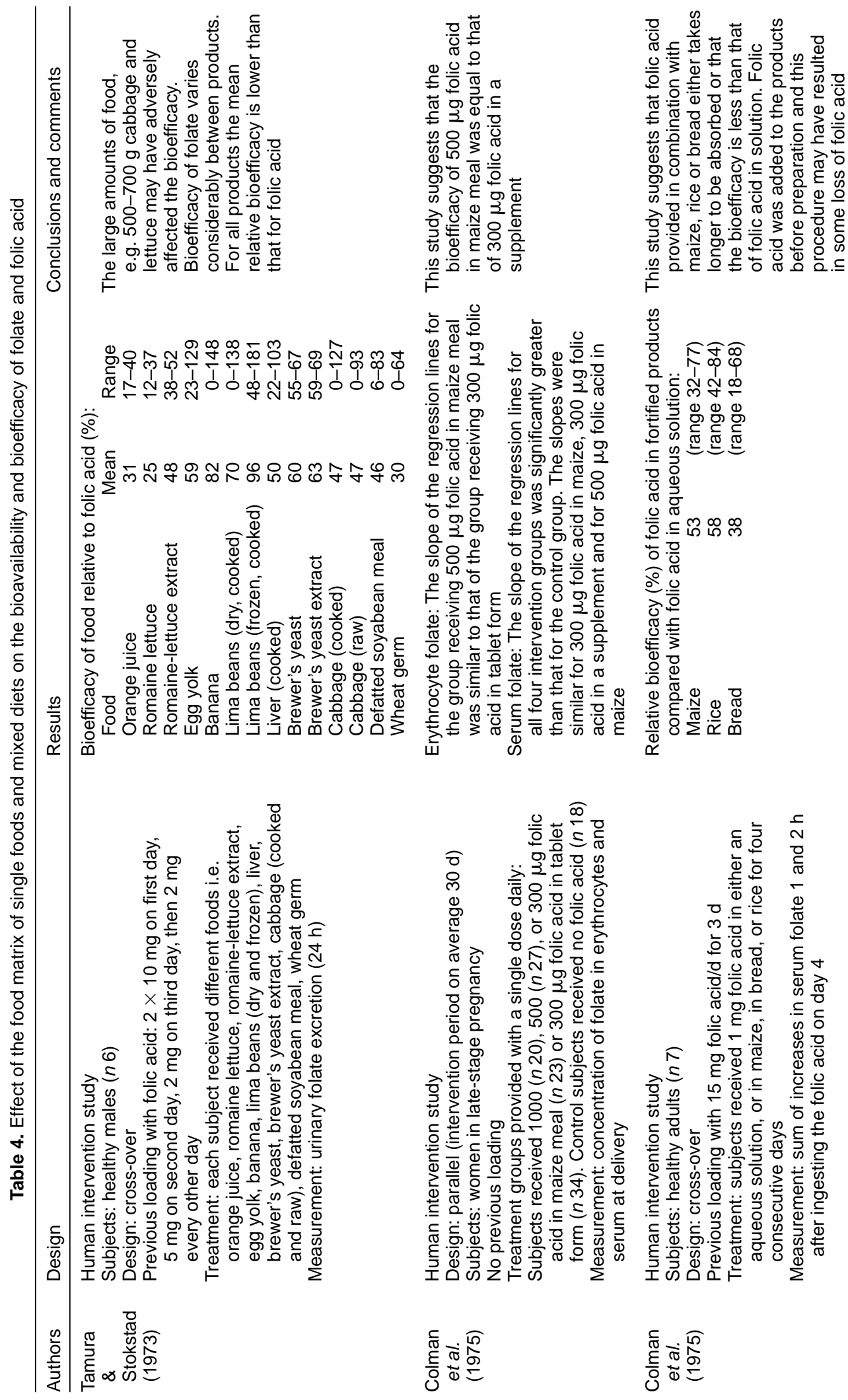




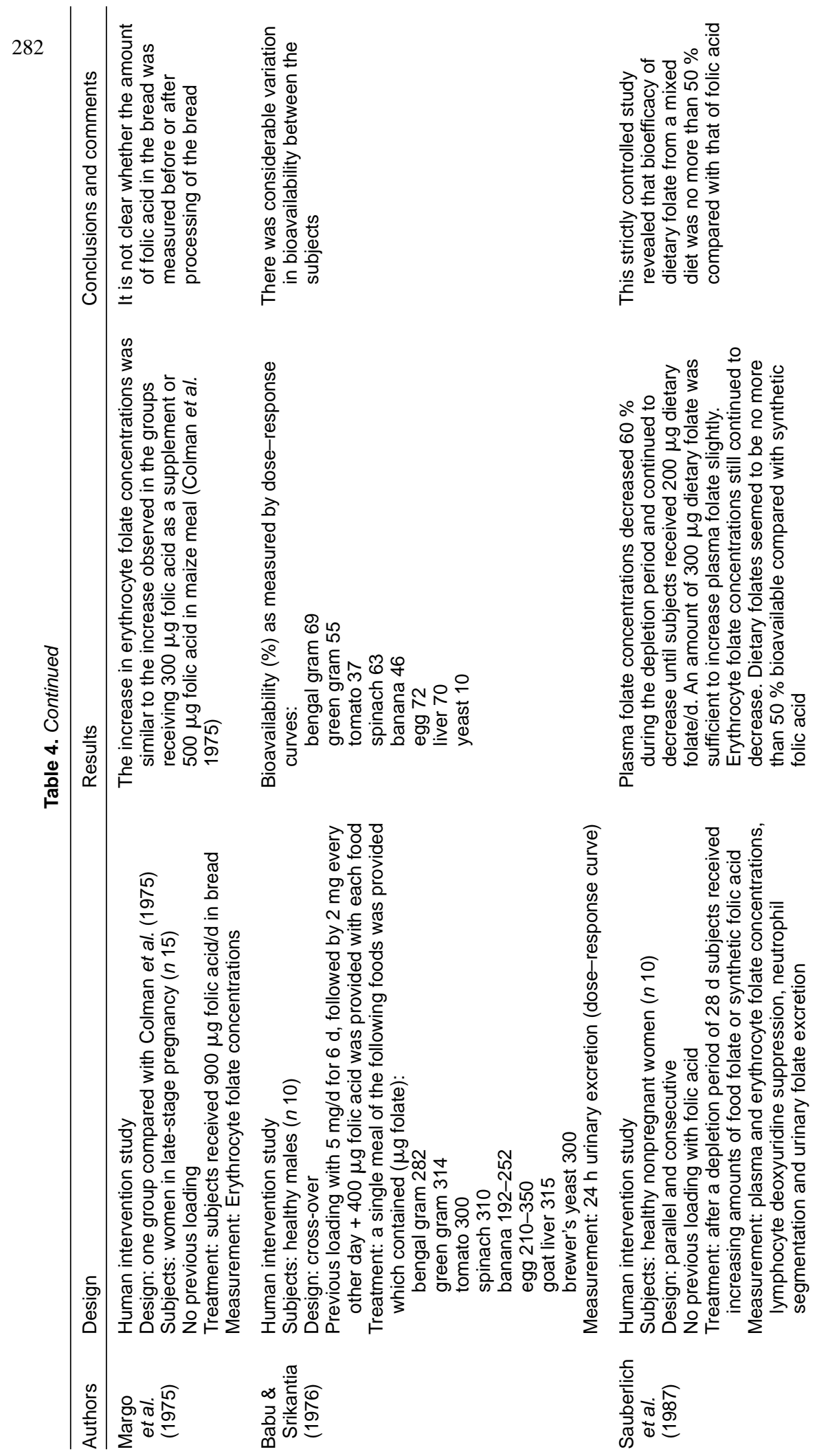




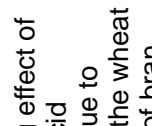

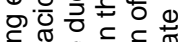

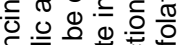

뜬은흥 뜡

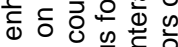

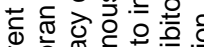

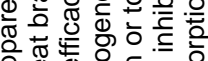

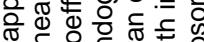

ه

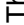

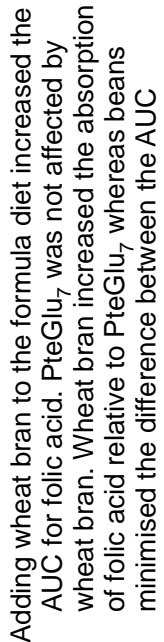

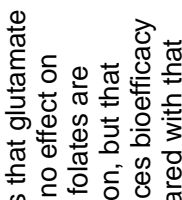

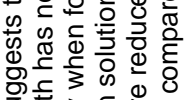

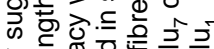

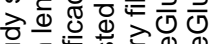

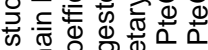

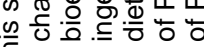
产

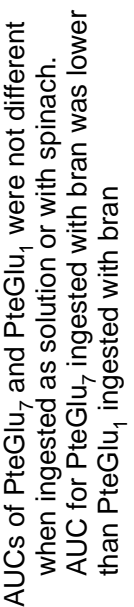

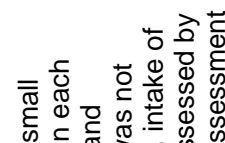

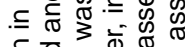

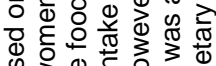

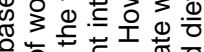

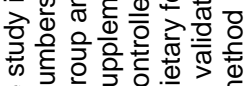

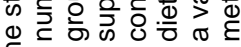

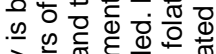

등 응

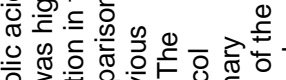

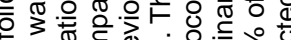

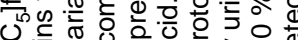

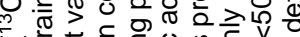

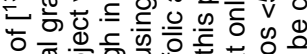

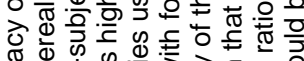
ช్ क d

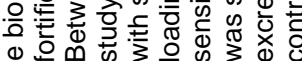
$\stackrel{\oplus}{\vdash}$

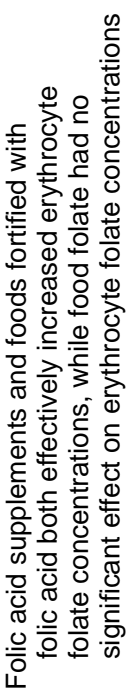

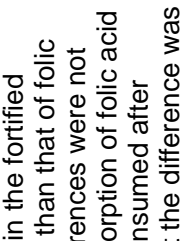

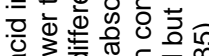
西

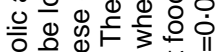

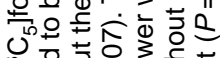
은

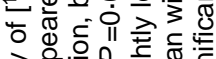

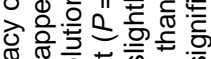

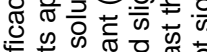

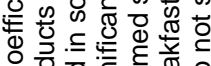

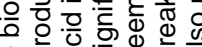

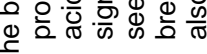
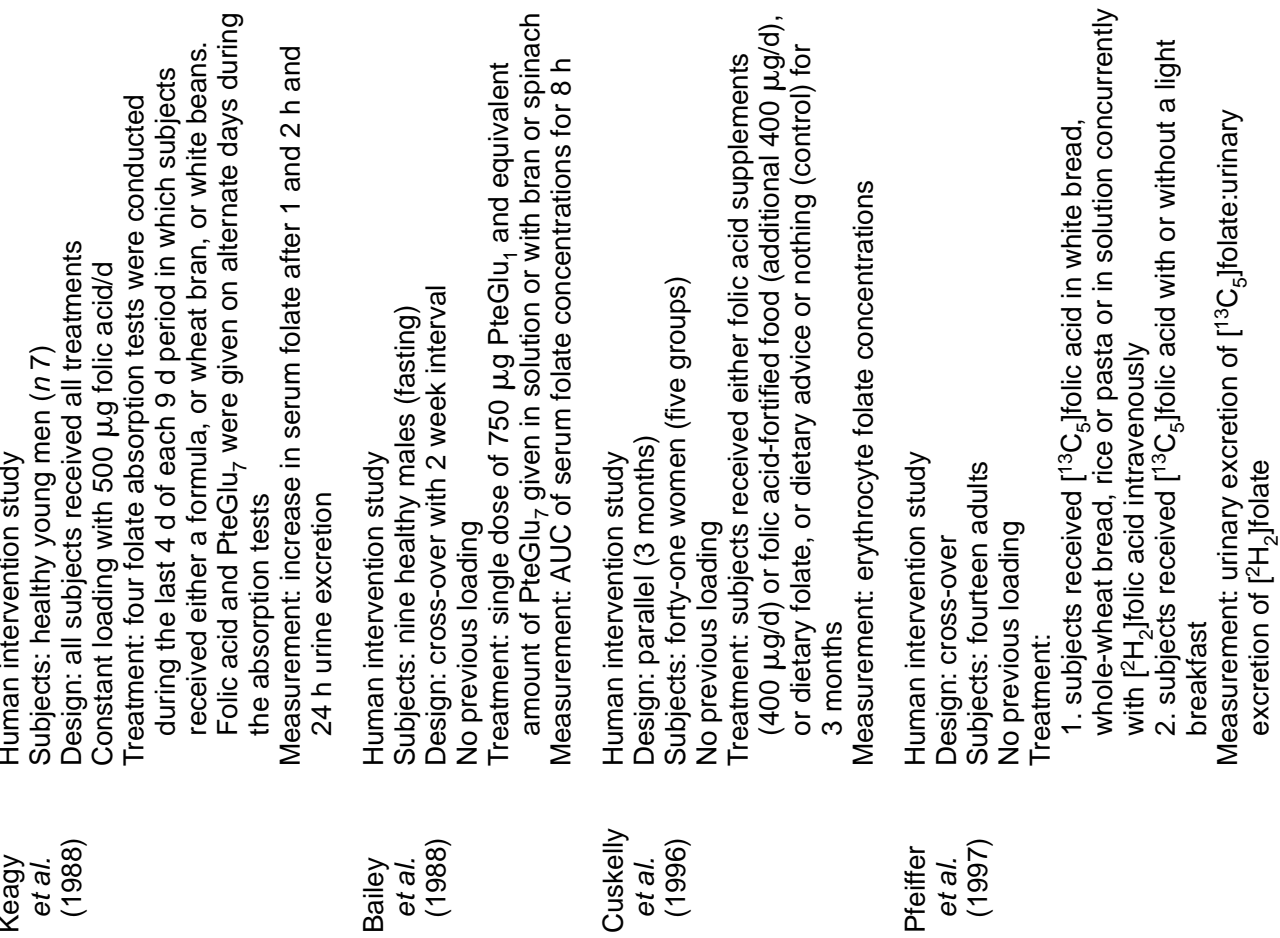

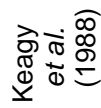

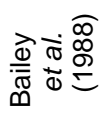

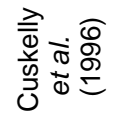

产 $\frac{\Phi}{\Phi}$ 


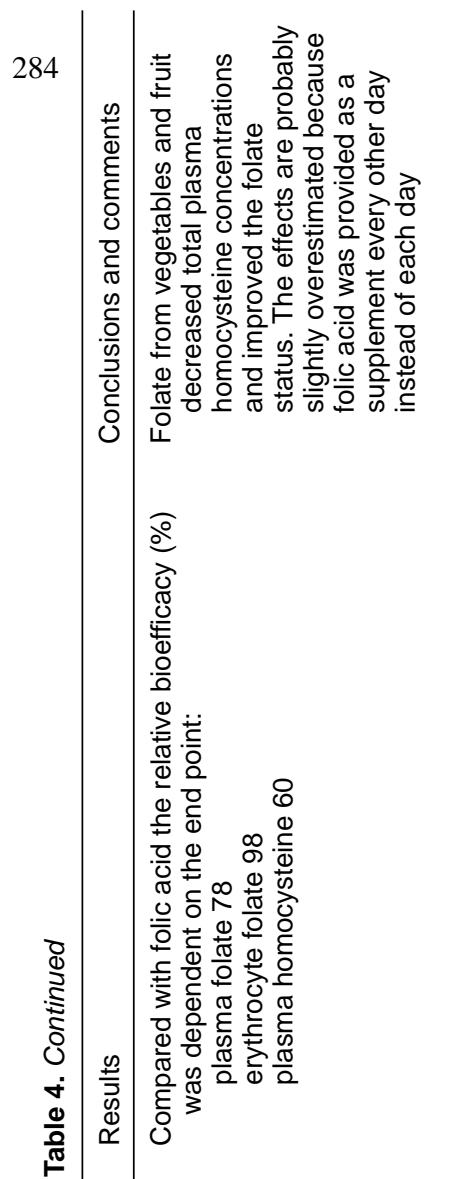

-

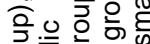

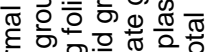

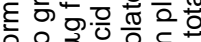

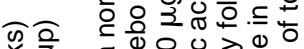

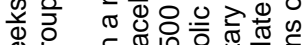
\省

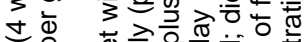

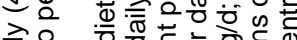

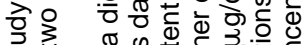

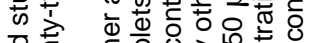
을

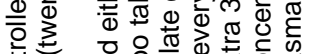

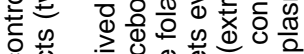

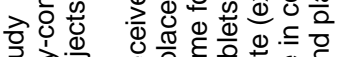

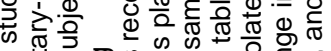

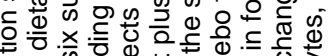

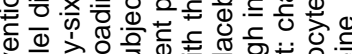

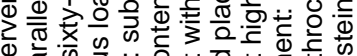

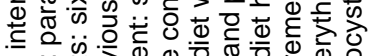

๘

๑)

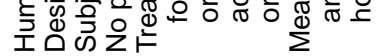

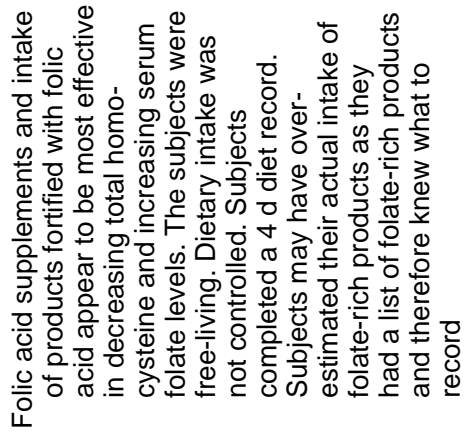

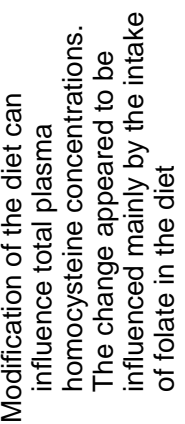

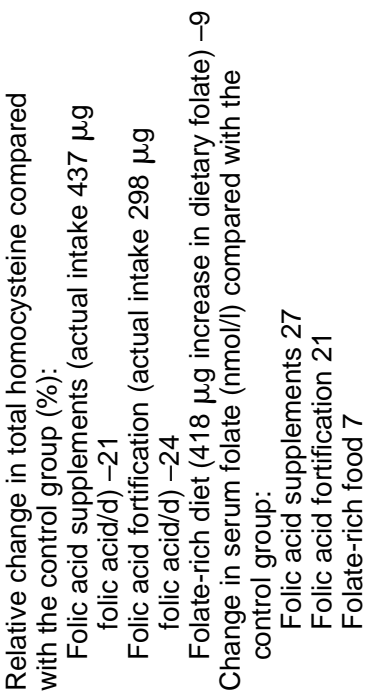

윰

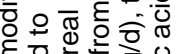

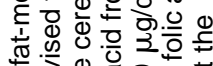

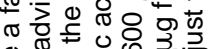

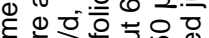

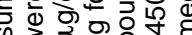

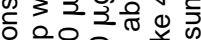

๙

응 흔

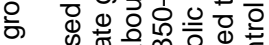

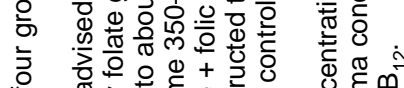

(⿻) ब तิ ब

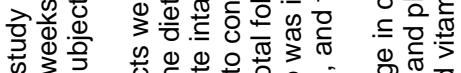
๘分

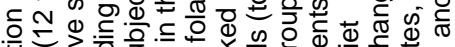

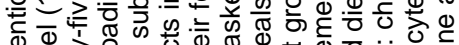
》

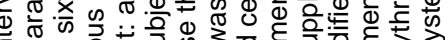

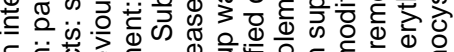

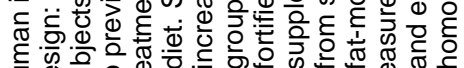

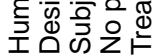

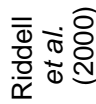

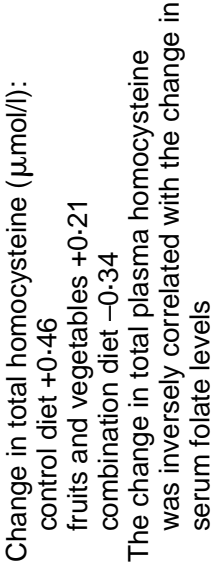

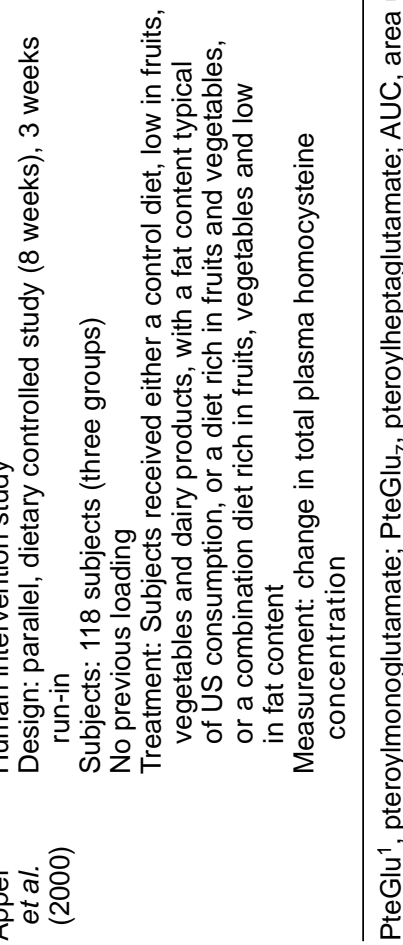


The US Federal Government introduced mandatory fortification of flour products with folic acid as from 1 January 1998. This action was taken in order to increase the folic acid intake of women in the fertile age-group, because an increased intake would be expected to lower the risk of having offspring with a neural-tube defect (US Department of Health and Human Services, Food and Drug Administration, 1996). Thus, it is important to know the bioefficacy of folic acid added as fortificant to flour, and the effect of other foods that may be eaten at the same time. It is now well established that the introduction of fortified flour products in the USA has improved the folate status of the population substantially. This improvement was shown in measurements made in middle-aged and older adults in the Framingham Offspring Study cohort (Jacques et al. 1999) and in California (Lawrence et al. 1999) since the fortification was introduced.

Several studies from a research group in Johannesburg (Colman et al. 1975; Margo et al. 1975; Colman, 1982) investigated the effects of maize meal, rice and bread on the bioefficacy of folic acid (Table 4). Bioefficacy of folic acid consumed with bread was found to be 58 (range 42-84) \% of that when it was consumed with water (Colman et al. 1975). In contrast, wheat bran has been found to stimulate rather than inhibit the serum folate response to ingested folic acid (Keagy et al. 1988). The enhancing effect of bran might be caused by endogenous folate in wheat bran, but interaction of bran with folate inhibitors cannot be excluded. Bailey et al. (1988) also showed no inhibitory effect of bran on the absorption of folic acid, although bran decreased absorption of pteroylheptaglutamate. Pfeiffer et al. (1997) used a dual-label stableisotope protocol to determine absorption of folic acid from fortified cereal-grain products. No significant differences were found between absorption of folic acid added to white bread, whole wheat bread, rice, pasta or water. The fact that the between-subject variation was high in this study may have considerably affected the interpretation of the results (Pfeiffer et al. 1997).

\section{Effect modifiers}

Effect modifiers are components in foods that influence nutrient bioavailability and bioefficacy. The effect of folate antagonists and other drugs will not be discussed in the present review.

Since the intestinal brush-border conjugase is $\mathrm{Zn}$ dependent, $\mathrm{Zn}$ intake and $\mathrm{Zn}$ status (see p. 286) can be expected to affect folate absorption. Supplementation with 3.5 or $14.5 \mathrm{mg} \mathrm{Zn/d}$ in combination with folic acid for $25 \mathrm{~d}$ was shown to have no effect on the concentration of folate in serum, erythrocytes and urine. This finding suggests that absorption of folic acid is not influenced by $\mathrm{Zn}$ intake (Kauwell et al. 1995). However, we are not aware of studies investigating the effect of $\mathrm{Zn}$ supplementation on the bioefficacy of dietary folate.

Certain components in the food may have the ability to inhibit the activity of the folate conjugase enzyme and thereby decrease the bioavailability of pteroylpolyglutamate. Tomatoes and orange juice inhibit the pteroylglutamate hydrolase (folate conjugase) activity in the human intestine (Bhandari \& Gregory, 1990). Furthermore, citrate, and to a lesser extent malate and formate, have been shown to affect intestinal brush-border conjugase activity in vitro (Wei \& Gregory, 1998). This finding suggests that organic acids affect the absorption of dietary polyglutamate folate by interfering with the intestinal deconjugation of the glutamate chain.

Alcohol could be another effect modifier. Folate deficiency is prevalent among chronic alcoholic patients whose dietary intake of minerals and vitamins is often inadequate. However, alcohol may also affect folate absorption (Halsted, 1995). In ethanol-fed pigs hydrolysis of pteroylpolyglutamates appears to be disturbed (Naughton et al. 1989; Reisenauer et al. 1989). This observation has not been confirmed in studies with human subjects, although ethanol 
ingestion in five chronic alcoholic patients increased urinary excretion of folic acid (Russell et al. 1983). In combination with a diet deficient in folate, intake of ethanol decreased the uptake of folic acid in alcoholic subjects (Halsted et al. 1971). In normal non-alcoholic subjects ingestion of ethanol also decreased plasma folate concentrations (Eichner \& Hillman, 1973). Thus, alcohol seems to affect folate bioefficacy.

\section{Nutrient status}

Status of the host with respect to folate, vitamin $\mathrm{B}_{12}$ and $\mathrm{Zn}$ may influence folate bioefficacy. Only a few studies have investigated the effect of folate status on folate bioavailability. Babu \& Lakshmaiah (1987) showed no effect of folate deficiency on jejunal conjugase activity in rats. To our knowledge, there are no studies comparing folate bioefficacy in folate-deplete and folate replete subjects. However, the study by Bower et al. (1993) showed that the increase in serum folate concentration after a pteroylpolyglutamate load $(4.5 \mathrm{mg}$ pteroylheptaglutamate) was higher in subjects with higher serum folate levels compared with subjects with lower baseline serum folate levels. This finding could be explained by a longer circulation time of folate in serum of replete subjects, implying that in depleted subjects folate is transferred rapidly from serum to tissues (Bower et al. 1993).

Distribution of folate over the tissues changes during folate deficiency. Liver of folate-deficient rats contains more polyglutamates of higher chain length than do those of folate-replete rats (Cassady et al. 1980; Ward \& Nixon, 1990; Varela-Moreiras \& Selhub, 1992). Folate concentrations decrease and chain length increases in liver, spleen and kidney in folate-deficient rats, but both concentration and chain length are similar in brain of folate-deficient and folatereplete rats (Richardson et al. 1979). Thus, folate status affects folate distribution over the tissues, but it is not clear whether it also affects folate bioefficacy.

Vitamin $B_{12}$ can influence folate bioefficacy, as its function is interrelated with that of folate. Methylcobalamin serves as a cofactor for methionine synthase, the enzyme responsible for the remethylation of homocysteine into methionine. In the same reaction 5-methyltetrahydrofolate is demethylated to provide tetrahydrofolate (Savage \& Lindenbaum, 1995). In cobalamin deficiency, 5-methyltetrahydrofolate cannot be converted to tetrahydrofolate. This lack of formation of tetrahydrofolate, referred to as the 'methyl folate trap', has consequences for the formation of other folate coenzymes (Herbert \& Zalusky, 1962). Although this theory has been criticised and many variations of the theory have been put forward (Savage \& Lindenbaum, 1995), all these variations suggest that vitamin $B_{12}$ deficiency influences folate bioefficacy because it changes the distribution of the various folate forms. This process also influences the overall folate status, because tetrahydrofolate is a much better substrate than 5-methyltetrahydrofolate for the enzyme folate polyglutamate synthetase. This enzyme is required for the synthesis of polyglutamates (Cichowicz \& Shane, 1987a,b). Polyglutamyl folates are retained better in cells and are more effective coenzymes than are monoglutamyl folates (Lowe et al. 1993).

Adequate $\mathrm{Zn}$ status is known to be important in folate bioefficacy. Tamura et al. (1978) showed that $\mathrm{Zn}$ depletion reduced the increase in serum folate concentration after supplementation with pteroylheptaglutamate by $53 \%$, while absorption of the monoglutamate form seemed to be unaffected (Tamura et al. 1978). This finding suggested that intestinal pteroylpolyglutamate hydrolase is $\mathrm{Zn}$ dependent and that $\mathrm{Zn}$ depletion inhibits hydrolysis of polyglutamates. Chandler et al. (1986) confirmed the Zn dependency of the brush-border folate hydrolase. Tamura (1995) reviewed the literature concerning the nutrient interaction of folate and $\mathrm{Zn}$. $\mathrm{He}$ 
concluded that although folate conjugase is $\mathrm{Zn}$ dependent its clinical significance is not clear (Tamura, 1995).

\section{Genetic factors}

Some genetic mutations are known to influence folate metabolism. This section will discuss some commonly-occurring genetic factors influencing folate bioavailability and bioefficacy.

In mice expression of the reduced folate carrier $R F C$ - 1 gene regulates the $\mathrm{pH}$-dependent folate absorption in the small intestine (Chiao et al. 1997). The organisation and structure of the human $R F C$ - 1 gene encoding for a folate transporter has also been determined (Tolner et al. 1998). However, the significance of this gene for folate absorption needs further investigation.

Another gene that is linked to folate status is the gene encoding for methylenetetrahydrofolate reductase. A variant of methylenetetrahydrofolate reductase was found to have lower specific activity and higher sensitivity to heat (Kang et al. 1988). This thermolabile variant is caused by an alanine-to-valine missense mutation (Goyette et al. 1994). Jacques et al. (1996) demonstrated that individuals homozygous for this mutation with plasma folate concentrations $<15.4 \mathrm{nmol} / \mathrm{l}$ had $24 \%$ higher fasting plasma total homocysteine concentrations than individuals with the normal genotype and similar plasma folate concentrations. No difference between genotypes was seen among individuals with plasma folate concentrations $\geqslant 15.4 \mathrm{nmol} / \mathrm{l}$. They suggested that individuals homozygous for this polymorphism need more folate to regulate their plasma homocysteine concentrations (Jacques et al. 1996). This observation implies that the functional bioefficacy of folate is diminished by this polymorphism when folate status is not optimal. However, high intakes of folate or of folic acid would seem to be able to overcome the negative effects of the polymorphism.

Methionine synthase is the enzyme involved in the remethylation reaction from homocysteine to methionine. To our knowledge, no polymorphisms in the gene encoding for this enzyme have been shown to influence folate status or functional bioefficacy.

\section{Host-related factors}

Host-related factors are factors of the host other than nutrient status and genetic factors that could influence bioavailability or bioefficacy. Examples of such factors are age, pregnancy, illness and malabsorption.

Bailey et al. (1984) investigated the absorption of pteroylpolyglutamates and pteroylmonoglutamates in different age-groups. They found that neither absorption nor activity of folate conjugase was affected by age.

Pregnancy increases the demand for folate. This higher demand may be explained by accelerated folate breakdown (Kownacki Brown et al. 1993; McPartlin et al. 1993). However, Caudill et al. (1997) found no differences between pregnant and non-pregnant women with respect to increase in serum folate or erythrocyte folate concentrations or in urinary excretion of 5-methyltetrahydrofolate after supplementation with 450 and $850 \mu \mathrm{g}$ folate/d. Although the same research group suggested, from results of a controlled dietary trial, that pregnant women made more efficient use of $450 \mu \mathrm{g}$ folic acid than of $850 \mu \mathrm{g}$ folic acid, they found no significant difference in catabolism between pregnant and non-pregnant women (Caudill et al. 1998). Thus, it is not clear what causes the higher demand for folate during pregnancy.

Two randomised trials have shown that folic acid supplementation in the periconceptional 
period reduces the risk of having offspring with neural-tube defects (Medical Research Council Vitamin Study Research Group, 1991; Czeizel \& Dudás, 1992). Decreased capacity to absorb folate by the mother has been suggested as a cause for the folate-related cases of neural-tube defects. However, Bower et al. (1993) showed that intestinal hydrolysis of pteroylpolyglutamates was not impaired in women who had previously had a child with a neural-tube defect. Moreover, Davis et al. (1995) found no difference in the absorption of folic acid between those mothers with and those without a history of bearing a child with a neural-tube defect (Davis et al. 1995). In contrast, Neuhouser et al. (1998) found that women who had previously given birth to a child with a neural-tube defect required a larger dose of folic acid or folate to elicit a plasma response equivalent to that of the general population. Thus, diminished maternal bioavailability of folate may lead to neural-tube defects in their offspring.

Halsted (1990) summarised studies from his group investigating the effect of gastrointestinal diseases on the absorption of ${ }^{3} \mathrm{H}$-labelled folate and ${ }^{14} \mathrm{C}$-labelled pteroylheptaglutamate. Absorption of folate and pteroylheptaglutamate was not affected by ulcerative colitis, but was diminished by tropical and coeliac sprue (Halsted, 1990). The saturable folate transport system in the jejunum, and thus folate bioavailability, is $\mathrm{pH}$ dependent, with an acidic $\mathrm{pH}$ optimum (Halsted, 1979; Mason, 1990).

\section{Mathematical interactions}

Mathematical interactions arise when the combined effect of two or more factors is different from that of the sum of separate effects of the factors. To our knowledge there are no reports in which this complicated problem has been addressed.

\section{Conclusions}

Various factors can influence bioavailability and bioefficacy of nutrients. Of the factors influencing bioavailability and bioefficacy of folate and folic acid, two stand out: the effect of the food matrix and the amount of folic acid consumed. Bioavailability of folate from some foods is less than $50 \%$ that of folic acid. The most likely explanation for this difference would be matrix factors: encapsulation and binding. However, often matrix effects cannot be distinguished from other factors, such as the form and chain length of folate in food. Food folate can be substituted with various $\mathrm{C}_{1}$ groups and with one to seven glutamate moieties. Although some studies suggest that $\mathrm{C}_{1}$ substitution of folate affects bioavailability, this effect seems to be only a minor factor. There is evidence that chain length affects bioavailability; studies in the present review suggest that polyglutamates are less bioavailable than monoglutamates. However, we think that differences in chain length can explain at most half the difference in bioefficacy between food folate and folic acid. Bioavailability and bioefficacy might also be influenced by other factors in food, such as organic acids. Indeed, organic acids have been shown in in vitro studies to inhibit the conjugase responsible for the removal of glutamate residues from polyglutamates to provide monoglutamates. Such a role for organic acids in decreasing the bioavailability of folate needs to be confirmed in in vivo studies. On the basis of the studies in the present review we conclude that matrix is the main factor influencing bioavailability and bioefficacy.

The amount of folic acid consumed also appears to be a very important factor. The bioavailability of folic acid provided in supplements is good. However, the homocysteine- 
lowering capacity (functional bioefficacy) of doses of folic acid $>500 \mu \mathrm{g}$ is limited, and it is not clear whether unmetabolised folic acid poses health risks. This factor is important, because now food fortification is implemented in many countries and folic acid supplements are freely available.

In particular circumstances host-related factors, such as illness and $\mathrm{pH}$ of the jejunum can influence bioavailability and bioefficacy. Genetic factors also deserve our attention in future research. Mutations of certain genes may influence folate bioavailability and bioefficacy. In this respect, we should not only search for mutations, but also investigate the clinical implication and possible therapies to overcome the negative impact of such mutations.

The techniques presently available for measuring bioavailability and bioefficacy make quantification of the effect of the various factors very difficult. The accuracy of most techniques depends on reaching a steady-state situation in the body. To establish such a state, most studies have used a folic acid preloading scheme to saturate tissues with folic acid. Saturation of the tissues reduces the intra-individual variation in response to treatment. However, it is not clear how this factor affects bioavailability and bioefficacy. Thus, further development of techniques such as stable-isotope techniques is needed. A major disadvantage of stable-isotope techniques is the availability, and hence the price, of a range of labelled compounds. Thus, it is difficult to obtain sufficient amounts of these compounds for experiments with sufficient subjects and/or of sufficient duration. This factor explains why no such intervention studies with appropriately large intervention groups have been carried out up until now. Stable-isotope studies could be improved by developing more sensitive methods for measuring isotopic enrichment of folate in plasma. This factor would enable studies to be carried out with limited perturbation of the steady-state and at lower cost. In conclusion, food matrix and the amount of folic acid consumed are the major factors influencing bioavailability and bioefficacy in healthy individuals. Food manufacturers can play an important role in increasing the bioavailability. Development of new methods of food preparation could modify the food matrix in such a way that folate will become more bioavailable. It is clear that processing and storage of foods can have negative effects on the amount of folate in food (Witthöft et al. 1999). Thus, future research should also focus on improving storage and processing techniques, so that more folate will be retained in the food until consumption. Optimum techniques for processing food at the household level to retain folate and to increase bioavailability should also be determined. Better bioavailability of food folate would make it easier for individuals to reach adequate folate status. Many individuals do not consume sufficient folate (Brussaard et al. 1995). Folate status can also be improved by increasing intake of folic acid. This increase could be achieved by consumption of foods fortified with folic acid and by using folic acid supplements. However, intakes of folic acid $>500 \mu \mathrm{g} / \mathrm{d}$ seem to have no additional functional bioefficacy, at least in healthy individuals without a genetic polymorphism that influences folate bioefficacy. Moreover, it is unclear whether such doses pose health risks. Thus, high intakes of folic acid by the general population should be avoided.

\section{Acknowledgement}

The authors would like to thank Alida Melse-Boonstra for her valuable comments with regard to the text. 


\section{References}

Appel LJ, Miller ER III, Jee SH, Stolzenberg-Solomon R, Lin P-H, Erlinger T, Nadeau MR \& Selhub J (2000) Effect of dietary patterns on serum homocysteine. Results of a randomized, controlled feeding study. Circulation 102, 852-857.

Babu S \& Lakshmaiah N (1987) Availability of food folate by liver folate repletion in rats. Nutrition Reports International 35, 831-836.

Babu S \& Srikantia SG (1976) Availability of folates from some foods. American Journal of Clinical Nutrition 29, 376-379.

Bailey LB, Barton LE, Hillier SE \& Cerda JJ (1988) Bioavailability of mono and polyglutamyl folate in human subjects. Nutrition Reports International 38, 509-518.

Bailey LB, Cerda JJ, Bloch BS, Busby MJ, Vargas L, Chandler CJ \& Halsted CH (1984) Effect of age on poly- and monoglutamyl folacin absorption in human subjects. Journal of Nutrition 114, 1770-1776.

Bhandari SD \& Gregory JF (1990) Inhibition by selected food components of human and porcine intestinal pteroylpolyglutamate hydrolase activity. American Journal of Clinical Nutrition 51, 87-94.

Bhandari SD \& Gregory JF (1992) Folic acid, 5-methyl-tetrahydrofolate and 5-formyl-tetrahydrofolate exhibit equivalent intestinal absorption, metabolism and in vivo kinetics in rats. Journal of Nutrition 122, 1847-1854.

Bonnette RE, Caudill MA, Boddie AM, Hutson AD, Kauwell GPA \& Bailey LB (1998) Plasma homocyst(e)ine concentrations in pregnant and nonpregnant women with controlled folate intake. Obstetrics and Gynecology $\mathbf{9 2}$ 167-170.

Boushey CJ, Beresford SA, Omenn, GS \& Motulsky AG (1995) A quantitative assessment of plasma homocysteine as a risk factor for vascular disease. Probable benefits of increasing folic acid intakes. Journal of the American Medical Association 274, 1049-1057.

Bower C, Stanley FJ, Croft M, de Klerk N, Davis RE \& Nicol DJ (1993) Absorption of pteroylpolyglutamates in mothers of infants with neural-tube defects. British Journal of Nutrition 69, 827-834.

Brouwer IA, van Dusseldorp M, Thomas CMG, Duran M, Hautvast JGAJ, Eskes TKAB \& Steegers Theunissen RPM (1999) Low-dose folic acid supplementation decreases plasma homocysteine: a randomized trial. American Journal of Clinical Nutrition 69, 99-104.

Brouwer IA, van Dusseldorp M, West CE, Meyboom S, Thomas CMG, Duran M, van het Hof KH, Eskes TKAB, Hautvast JGAJ \& Steegers Theunissen RPM (1999) Dietary folate from vegetables and citrus fruit decreases plasma homocysteine concentrations in humans in a dietary controlled study. Journal of Nutrition 129, 1135-1139.

Brown JP, Scott JM, Foster FG \& Weir DG (1973) Ingestion and absorption of naturally occurring pteroylmonoglutamates (folates) in man. Gastroenterology 64, 223-232.

Brussaard JH, van der Berg H, Brants HAM, van Loon CJAM \& Löwik MRH (1995) Folate Intake and Status among Adults in The Netherlands (Dutch Nutrition Surveillance System). Descriptive Statistics. Zeist, The Netherlands: TNO Nutrition.

Cassady IA, Budge MM, Healy MJ \& Nixon PF (1980) An inverse relationship of rat liver folate polyglutamate chain length to nutritional folate sufficiency. Biochimica et Biophysica Acta 633, 258-268.

Castenmiller JJM \& West CE (1998) Bioavailability and conversion of carotenoids. Annual Review of Nutrition 18, 19-38.

Caudill MA, Cruz AC, Gregory JF, Hutson AD \& Bailey LB (1997) Folate status response to controlled folate intake in pregnant women. Journal of Nutrition 127, 2363-2370.

Caudill MA, Gregory JF, Hutson AD \& Bailey LB (1998) Folate catabolism in pregnant and nonpregnant women with controlled folate intakes. Journal of Nutrition 128, 204-208.

Chandler CJ, Wang XL \& Halsted CH (1986) Pteroylpolyglutamate hydrolase from human jejunal brush borders; purification and characterization. Journal of Biological Chemistry 261, 928-933.

Chiao JH, Roy K, Tolner B, Yang C-H \& Sirotnak FM (1997) RFC-1 gene expression regulates folate absorption in mouse small intestine. Journal of Biological Chemistry 272, 11165-11170.

Cichowicz DJ \& Shane B (1987a) Mammalian folylpoly-gamma-glutamate synthetase. 1. Purification and general properties of the hog liver enzyme. Biochemistry 26, 504-512.

Cichowicz DJ \& Shane B (1987b). Mammalian folylpoly-gamma-glutamate synthetase. 2. Substrate specificity and kinetic properties. Biochemistry 26, 513-521.

Colman N (1982) Addition of folic acid to staple foods as a selective nutrition intervention strategy. Nutrition Reviews 40, 225-233.

Colman N, Green R \& Metz J (1975) Prevention of folate deficiency by food fortification. II. Absorption of folic acid from fortified staple foods. American Journal of Clinical Nutrition 28, 459-464.

Cuskelly GJ, McNulty H \& Scott JM (1996) Effect of increasing dietary folate on red-cell folate: implications for prevention of neural tube defects. Lancet 347, 657-659.

Czeizel AE \& Dudás I (1992) Prevention of the first occurrence of neural-tube defects by periconceptional vitamin supplementation. New England Journal of Medicine 327, 1832-1835.

Davis BA, Bailey LB, Gregory JF, Toth JP, Dean J \& Stevenson RE (1995) Folic acid absorption in women with a history of pregnancy with neural tube defect. American Journal of Clinical Nutrition 62, 782-784.

de Pee S \& West CE (1996) Dietary carotenoids and their role in combating vitamin A deficiency: a review of the literature. European Journal of Clinical Nutrition 50, Suppl 3, S38-S53. 
Eichner ER \& Hillman RS (1973) Effect of alcohol on serum folate level. Journal of Clinical Investigation 52, 584-591.

Godwin HA \& Rosenberg IH (1975) Comparative studies of the intestinal absorption of [3H]pteroylmonoglutamate and [3H]pteroylheptaglutamate in man. Gastroenterology 69, 364-373.

Goyette P, Sumner JS, Milos R, Duncan AM, Rosenblatt DS, Matthews RG \& Rozen R (1994) Human methylenetetrahydrofolate reductase: isolation of cDNA, mapping and mutation identification. Nature Genetics 7, 195-200, 551.

Graham IM, Daly LE, Refsum HM et al. (1997) Plasma homocysteine as a risk factor for cardiovascular disease. Journal of the American Medical Association 277, 1775-1781.

Gregory JF, Bhandari SD, Bailey LB, Toth JP, Baumgartner TG \& Cerda, JJ (1991) Relative bioavailability of deuterium-labeled monoglutamyl and hexaglutamyl folates in human subjects. American Journal of Clinical Nutrition 53, 736-740.

Gregory JF, Bhandari SD, Bailey LB, Toth JP, Baumgartner TG \& Cerda, JJ (1992). Relative bioavailability of deuterium-labeled monoglutamyl tetrahydrofolates and folic acid in human subjects. American Journal of Clinical Nutrition 55, 1147-1153.

Halsted CH (1979) The intestinal absorption of folates. American Journal of Clinical Nutrition 32, 846-855.

Halsted CH (1990) Intestinal absorption of dietary folates. In Folic Acid Metabolism in Health and Disease, 1st ed., pp. 23-45 [MF Picciano, ELR Stokstad and JF Gregory III, editors]. New York: Wiley-Liss.

Halsted CH (1995) Alcohol and folate interactions: Clinical implications. In Folate in Health and Disease, pp. 313-327 [LB Bailey, editor]. New York: Marcel Dekker.

Halsted CH, Baugh CM \& Butterworth CE (1975) Jejunal perfusion of simple and conjugated folates in man. Gastroenterology 68, 261-269.

Halsted CH, Reisenauer AM, Shane B \& Tamura T (1978) Availability of monoglutamyl and polyglutamyl folates in normal subjects and in patients with coeliac sprue. Gut 19, 886-891.

Halsted CH, Robles EA \& Mezey E (1971) Decreased jejunal uptake of labeled folic acid (3H-PGA) in alcoholic patients: roles of alcohol and malnutrition. New England Journal of Medicine 285, 701-706.

Herbert V \& Zalusky R (1962) Interrelations of vitamin B12 and folic acid metabolism: folic acid clearance studies. Journal of Clinical Investigation 41, 1263-1276.

Heseker H \& Schmitt G (1987) Effect of long-term supplementation of folate on folate status in plasma and erythrocytes. Journal of Nutritional Sciences and Vitaminology 33, 163-168.

Homocysteine Lowering Trialists' Collaboration (1998) Lowering blood homocysteine with folic acid based supplements: meta-analysis of randomised trials. British Medical Journal 316, 894-898.

Jacob RA, Pianalto FS, Henning SM, Zhang JZ \& Swendseid ME (1995) In vivo methylation capacity is not impaired in healthy men during short-term dietary folate and methyl group restriction. Journal of Nutrition 125, 1495-1502.

Jacques PF, Bostom AG, Williams RR, Ellison RC, Eckfeldt JH, Rosenberg IH, Selhub J \& Rozen R (1996) Relation between folate status, a common mutation in methylenetetrahydrofolate reductase, and plasma homocysteine concentrations. Circulation 93, 7-9.

Jacques PF, Selhub J, Bostom AG, Wilson PWF \& Rosenberg IH (1999) The effect of folic acid fortification on plasma folate and total homocysteine concentrations. New England Journal of Medicine 340, 1449-1454.

Kang S-S, Zhou J, Wong PWK, Kowalysin J \& Strokosch G (1988) Intermediate homocysteinemia: a thermolabile variant of methylenetetrahydrofolate reductase. American Journal of Human Genetics 43, 414-421.

Kauwell GPA, Bailey LB, Gregory JF, Bowling DW \& Cousins RJ (1995) Zinc status is not adversely affected by folic acid supplementation and zinc does not impair folate utilization in human subjects. Journal of Nutrition 125, 66-72.

Keagy PM, Shane B \& Oace SM (1988) Folate bioavailability in humans: effects of wheat bran and beans. American Journal of Clinical Nutrition 47, 80-88.

Kelly P, McPartlin JM, Goggins M, Weir DG \& Scott JM (1997) Unmetabolized folic acid in serum: acute studies in subjects consuming fortified food and supplements. American Journal of Clinical Nutrition 65, 1790-1795.

Kownacki Brown PA, Wang C, Bailey LB, Toth JP \& Gregory JF (1993) Urinary excretion of deuterium-labeled folate and the metabolite $p$-aminobenzoylglutamate in humans. Journal of Nutrition 123, 1101-1108.

Lawrence JM, Petiti DB, Watkins M \& Umekubo MA (1999) Trends in serum folate after food fortification. Lancet 354, 915-916.

Lowe KE, Osborne CB, Lin BF, Kim JS, Hsu JC \& Shane B (1993) Regulation of folate and one-carbon metabolism in mammalian cells. II. Effect of folylpoly-gamma-glutamate synthetase substrate specificity and level on folate metabolism and folylpoly-gamma-glutamate specificity of metabolic cycles of one-carbon metabolism. Journal of Biological Chemistry 268, 21665-21673.

McPartlin JM, Halligan A, Scott JM, Darling MD \& Weir DG (1993) Accelerated folate breakdown in pregnancy. Lancet 341, 148-149.

Malinow MR, Duell PB, Hess DL, Anderson PH, Kruger WD, Phillipson BE, Gluckman RA, Block PC \& Upson BM (1998) Reduction of plasma homocyst(e)ine levels by breakfast cereal fortified with folic acid in patients with coronary heart disease. New England Journal of Medicine 338, 1009-1015.

Margo G, Barker M, Fernandez-Costa F, Colman N, Green R \& Metz J (1975) Prevention of folate deficiency by food fortification. VII. The use of bread as a vehicle for folate supplementation. American Journal of Clinical Nutrition 28, 761-763.

Mason JB (1990) Intestinal transport of monoglutamyl folates in mammalian systems. In Folic Acid Metabolism in 
Health and Disease, 1st ed, pp. 47-64 [MF Picciano, ELR Stokstad and JF Gregory III, editors]. New York: WileyLiss.

Medical Research Council Vitamin Study Research Group (1991) Prevention of neural tube defects: Results of the Medical Research Council Vitamin Study. Lancet 338, 131-137.

Naughton CA, Chandler CJ, Duplantier RB \& Halsted CH (1989) Folate absorption in alcoholic pigs: in vitro hydrolysis and transport at the intestinal brush border membrane. American Journal of Clinical Nutrition 50, 1436-1441.

Neuhouser ML, Beresford SAA, Hickok DE \& Monsen ER (1998) Absorption of dietary folate and supplemental folate in women with prior pregnancies with neural tube defects and controls. Journal of the American College of Nutrition 6, 625-630.

Perry J \& Chanarin I (1970) Intestinal absorption of reduced folate compounds in man. British Journal of Haematology 18, 329-339.

Perry J \& Chanarin I (1973) Formylation of folates as a step in physiological folate absorption. British Medical Journal ii, $58-59$.

Pfeiffer CM, Rogers LM, Bailey LB \& Gregory JF (1997) Absorption of folate from fortified cereal-grain products and of supplemental folate consumed with or without food determined by using a dual-label stable-isotope protocol. American Journal of Clinical Nutrition 66, 1388-1397.

Pietrzik K \& Remer T (1989) Zur Bioverfugbarkeitsprufung von Mikronahrstoffen (Bioavailability study of micronutrients). Zeitschrift für Ernahrungswissenschaft 28, 130-141.

Reisenauer A \& Halsted C (1987) Human folate requirements. Journal of Nutrition 117, 600-602.

Reisenauer AM, Buffington CAT, Villanueva JA \& Halsted CH (1989) Folate absorption in alcoholic pigs: in vivo intestinal perfusion studies. American Journal of Clinical Nutrition 50, 1429-1435.

Reisenauer AM, Krumdieck CL \& Halsted CH (1977) Folate conjugase: two separate activities in human jejunum. Science 198, 196-197.

Retief FP (1969) Urinary folate excretion after ingestion of pteroylmonoglutamic acid and food folate. American Journal of Clinical Nutrition 22, 352-355.

Richardson RE, Healy MJ \& Nixon PF (1979) Folates of rat tissue. Bioassay of tissue folylpolyglutamates and a relationship of liver folylpolyglutamates to nutritional folate sufficiency. Biochimica et Biophysica Acta 585, 128-133.

Riddell LJ, Chisholm A, Williams S \& Mann JI (2000) Dietary strategies for lowering homocysteine concentrations. American Journal of Clinical Nutrition 71, 1448-1454.

Rogers LM, Pfeiffer CM, Bailey LB \& Gregory JF (1997) A dual-label stable-isotopic protocol is suitable for determination of folate bioavailability in humans: evaluation of urinary excretion and plasma folate kinetics of intravenous and oral doses of [13C5] and [2H2]folic acid. Journal of Nutrition 127, 2321-2327.

Rosenberg IH \& Godwin HA (1971) The digestion and absorption of dietary folate. Gastroenterology 60, 445-463.

Rowland M \& Tozer TN (1989) Clinical Pharmacokinetics: Concepts and Applications. Philadelphia, PA: Lea and Febiger.

Russell RM, Rosenberg IH, Wilson PD, Iber FL, Oaks EB, Giovetti AC, Otradovec CL, Karwoski PA \& Press AW (1983) Increased urinary excretion and prolonged turnover time of folic acid during ethanol ingestion. American Journal of Clinical Nutrition 38, 64-70.

Sauberlich HE, Kretsch MJ, Skala JH., Johnson HL \& Taylor PC (1987) Folate requirement and metabolism in nonpregnant women. American Journal of Clinical Nutrition 46, 1016-1028.

Savage DG \& Lindenbaum JL (1995) Folate-cobalamin interactions. In Folate in Health and Disease, pp. 237-285 [LB Bailey, editor]. New York, Marcel Dekker.

Schorah CJ, Devitt H, Lucock M \& Dowell AC (1998) The responsiveness of plasma homocysteine to small increases in dietary folic acid: a primary care study. European Journal of Clinical Nutrition 52, 407-411.

Selhub J, Brin H \& Grossowicz N (1973) Uptake and reduction of radioactive folate by everted sacs of rat small intestine. European Journal of Biochemistry 33, 433-438.

Selhub J, Dhar GJ \& Rosenberg IH (1983) Gastrointestinal absorption of folates and antifolates. Pharmacology and Therapeutics 20, 397-418.

Shane B (1995) Folate chemistry and metabolism. In Folate in Health and Disease, pp. 1-22 [LB Bailey, editor]. New York: Marcel Dekker.

Strum WB (1979) Enzymatic reduction and methylation of folate following pH-dependent carrier-mediated transport in rat jejunum. Biochimica et Biophysica Acta 554, 249-257.

Tamura T (1995) Nutrient interaction of folate and zinc. In Folate in Health and Disease, pp. 287-312 [LB Bailey, editor]. New York: Marcel Dekker.

Tamura T, Shane B, Baer MT, King JC, Margen S \& Stokstad ELR (1978) Absorption of mono- and polyglutamyl folates in zinc-depleted man. American Journal of Clinical Nutrition 31, 1984-1987.

Tamura T \& Stokstad ELR (1973) The availability of food folate in man. British Journal of Haematology 25, 513-532.

Tolner B, Roy K \& Sirotnak FM (1998) Structural analysis of the human RFC-1 gene encoding a folate transporter reveals multiple promotors and alternatively spliced transcrips with 5' end heterogeneity. Gene 211, 331-341.

Truswell AS \& Kounnavong S (1997) Quantitative responses of serum folate to increasing intakes of folic acid in healthy women. European Journal of Clinical Nutrition 51, 839-845.

US Department of Health and Human Services, Food and Drug Administration (1996) Food standards: amendment of the standards of identity for enriched grain products to require addition of folic acid. Federal Register 61, 8781-8807. 
Van Lieshout M, West CE, Muhilal, Permaesih D, Wang Y, Xu X, Van Breemen RB, Creemers AFL, Verhoeven MA \& Lugtenburg J (2001) Bioefficacy of beta-carotene dissolved in oil studied in children in Indonesia. American Journal of Clinical Nutrition 73, 949-958.

Varela-Moreiras G \& Selhub J (1992) Long-term folate deficiency alters folate content and distribution differentially in rat tissues. Journal of Nutrition 122, 986-991.

Wagner C (1995) Biochemical role of folate in cellular metabolism. In Folate in Health and Disease, pp. 23-42 [LB Bailey, editor]. New York: Marcel Dekker.

Ward GJ \& Nixon PF (1990) Modulation of pteroylpolyglutamate concentration and length in response to altered folate nutrition in a comprehensive range of rat tissues. Journal of Nutrition 120, 476-484.

Ward M, McNulty H, McPartlin J, Strain JJ, Weir DG \& Scott JM (1997) Plasma homocysteine, a risk factor for cardiovascular disease, is lowered by physiological doses of folic acid. Quarterly Journal of Medicine 90, 519-524.

Wei MM, Bailey LB, Toth JP \& Gregory JF (1996) Bioavilability for humans of deuterium-labeled monoglutamyl and polyglutamyl folates is affected by selected foods. Journal of Nutrition 126, 3100-3108.

Wei MM \& Gregory JF (1998) Organic acids in selected foods inhibit intestinal brush border pteroylpolyglutamate hydrolase in vitro: potential mechanism affecting the bioavailability of dietary polyglutamyl folate. Journal of Agricultural and Food Chemistry 46, 211-219.

Witthöft CM, Forssén K, Johannesson L \& Jägerstad M (1999) Folates -food sources, analyses, retention and bioavailability. Scandinavian Journal of Nutrition/Närinsforskning 43, 138-146. 


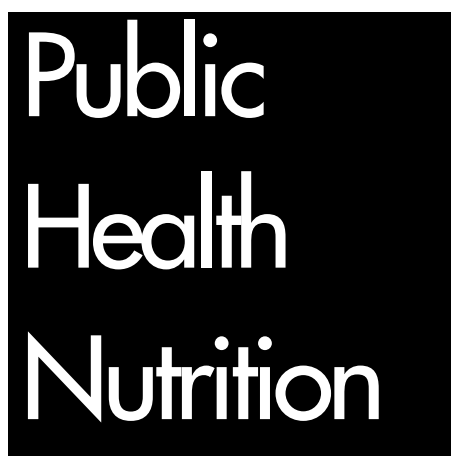

AN INTERNATIONAL RESEARCH JOURNAL PUBLISHED BY CABI PUBLISHING ON BEHALF OF THE NUTRITION SOCIETY

\section{To order your subscription or for more information contact:}

\section{CABI Publishing,}

CAB International,

Wallingford,

Oxon, OX10 8DE, UK

Tel: +44 (0)1491832111

Fax: +44 (0)1491 829292

Email: publishing@cabi.org

\section{CABI Publishing,}

$C A B$ International,

10 East 40th Street,

Suite 3203,

New York, NY 10016, USA

Tel: 2124817018

Toll free: 8005284841

Fax: 2126867993

Email: cabi-nao@cabi.org

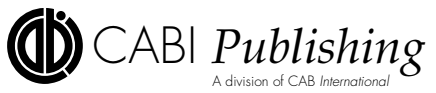

Publishes Public Health Nutrition on behalf of The Nutrition Society
Available on the Internet at

www.cabi-publishing.org/journals

\section{Journal Editors}

Dr Barrie Margetts (Editor-in-Chief)

Institute of Human Nutrition

University of Southampton, UK

Dr Lenore Arab

(Editor, North America)

Schools of Public Health and Medicine,

University of North Carolina at Chapel Hill, USA

- Essential reading for everyone involved in public health nutrition, practitioners and researchers

- The source for an evidence based approach to the solution of nutrition related health problems

- Recently described by an eminent international scientist as essential reading for all people working in this field

\begin{tabular}{|c|c|c|}
\hline Print only & Internet only & $\begin{array}{l}\text { Print/Internet } \\
\text { Package }\end{array}$ \\
\hline $\begin{array}{l}£ 275.00 \\
\$ 480.00 \text { Americas only } \\
€ 435.00 \text { EU only }\end{array}$ & $\begin{array}{l}£ 265.00 \\
\$ 465.00 \text { Americas only } \\
€ 420.00 \text { EU only }\end{array}$ & $\begin{array}{l}£ 285.00 \\
\$ 500.00 \text { Americas only } \\
€ 455.00 \text { EU only }\end{array}$ \\
\hline
\end{tabular}

A special subscription rate is available for members of The Nutrition Society

Print only, Internet only and Internet/Print Package price \$85.00 North and South America

$£ 52.00$ Rest of the World $\neq 80.00$ Europe

\section{Volume 5 in 6 issues}

We also publish special issues that cover proceedings of meetings or other special reports (all included at no extra cost).

Electronic and paper copies available.

If you have research findings of interest to a wide Public Health Nutrition audience send us your work. For details on layout consult any issue of the journal or visit our web site.

For more information about The Nutrition Society visit www.nutsoc.org.uk 